\title{
RECENT RESEARCH ON THE GROWTH PLATE Advances in fibroblast growth factor signaling in growth plate development and disorders
}

\author{
Yangli Xie, Siru Zhou, Hangang Chen, Xiaolan Du and Lin Chen \\ Department of Rehabilitation Medicine, Center of Bone Metabolism and Repair, Trauma Center, \\ State Key Laboratory of Trauma, Burns and Combined Injury, Institute of Surgery Research, \\ Daping Hospital, Third Military Medical University, Chongqing 400042, China
}

Correspondence should be addressed to $X$ Du or L Chen Emails

DXL_xiaolan@163.com or linchen70@163.com

\begin{abstract}
Skeletons are formed through two distinct developmental actions, intramembranous ossification and endochondral ossification. During embryonic development, most bone is formed by endochondral ossification. The growth plate is the developmental center for endochondral ossification. Multiple signaling pathways participate in the regulation of endochondral ossification. Fibroblast growth factor (FGF)/FGF receptor (FGFR) signaling has been found to play a vital role in the development and maintenance of growth plates. Missense mutations in FGFs and FGFRs can cause multiple genetic skeletal diseases with disordered endochondral ossification. Clarifying the molecular mechanisms of FGFs/FGFRs signaling in skeletal development and genetic skeletal diseases will have implications for the development of therapies for FGF-signaling-related skeletal dysplasias and growth plate injuries. In this review, we summarize the recent advances in elucidating the role of FGFs/FGFRs signaling in growth plate development, genetic skeletal disorders, and the promising therapies for those genetic skeletal diseases resulting from FGFs/FGFRs dysfunction. Finally, we also examine the potential important research in this field in the future.
\end{abstract}

\section{Introduction on growth plate development}

The skeleton is formed through endochondral or intramembranous ossification (Olsen et al. 2000, Long \& Ornitz 2013). The skull and the inner clavicles are formed through intramembranous ossification. The majority of bone is formed by endochondral ossification, including the ribs, limb bones, and vertebrae (Fig. 1). Endochondral ossification is a highly regulated process, starting from initiation of mesenchyme condensation. Mesenchyme differentiates into chondrocytes and forms the cartilage anlage. During endochondral ossification the chondrocytes undergo an orderly sequence of events: proliferation, hypertrophy, mineralization, and apoptosis, leaving the mineralized cartilaginous templates, which will be replaced by bone tissues through osteogenesis. Osteogenesis can be triggered by multiple factors released from both prehypertrophic and hypertrophic chondrocytes, such as Indian hedgehog ( $\mathrm{IHH})$ and vascular endothelial growth factor (VEGF), which induce the differentiation of perichondrial cells into osteoblasts, and also the invasion of blood vessels into the mineralized cartilage, bringing

Published by Bioscientifica Ltd

This paper is one of 4 papers in a thematic review section on Recent Research on the Growth Plate: Regulation, Injury and Regeperation. The questeditor for this section : $51: 46 \mathrm{AM}$ was Cory Xian, University of South Australia Adelaide, Australia. 


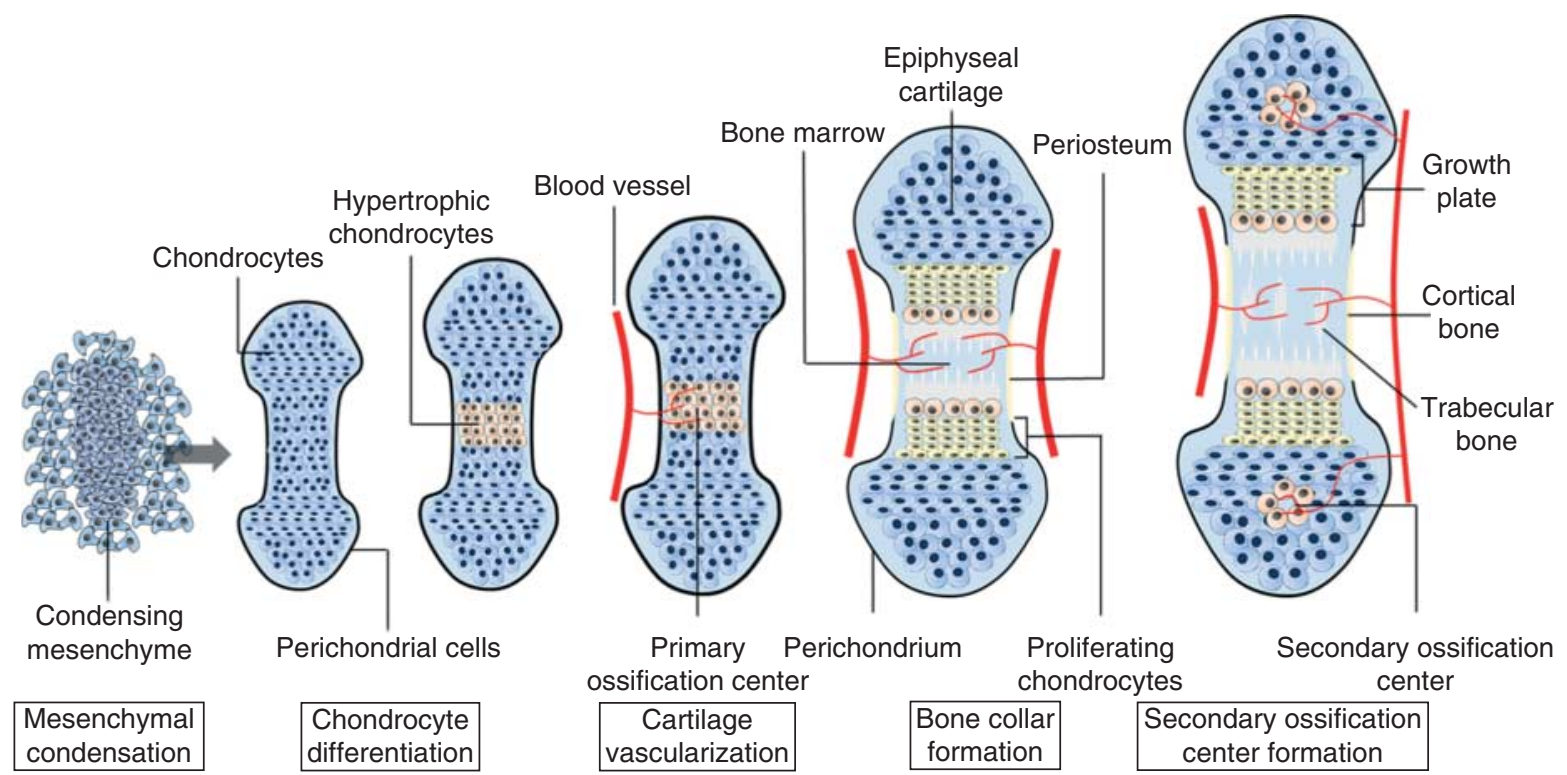

\section{Figure 1}

Endochondral bone development. After condensation, mesenchyme gradually differentiates into chondrocytes and forms a cartilage template.Then the chondrocytes will go through hypertrophy, mineralization, and finally apoptosis, leaving the mineralized cartilaginous template. With

the osteoclasts and osteoprogenitors to the cartilaginous templates to replace the growth plate cartilage with bone through their bone resorption and formation function respectively (Karsenty \& Wagner 2002, Provot \& Schipani 2005, Maes et al. 2010, Long \& Ornitz 2013).

The growth plate has been described as the developmental center for endochondral ossification. The chondrocytes exhibit distinct and observable stages during this process (Wuelling \& Vortkamp 2010). The growth plate can easily be subdivided into four zones on the basis of the shape and function of the chondrocytes (Burdan et al. 2009). The resting zone is constituted by small round chondrocytes adjacent to the articular surface. These cells undergo differentiation into proliferative flat chondrocytes to form proliferative columns. The resting and proliferating chondrocytes secrete collagen type II (COL2), aggrecan, and other matrix proteins to form cartilage matrix. The proliferative chondrocytes differentiate into prehypertrophic and thereafter hypertrophic chondrocytes, which secrete collagen type $\mathrm{X}$ toward the diaphysis. Prehypertrophic chondrocytes are essential for controlling the pace of endochondral ossification. A variety of molecules regulate growth plate development by controlling prehypertrophic differentiation (Maes et al. 2010). Hypertrophic chondrocytes remodel the cartilage matrix into a calcifying matrix (Ortega et al. 2004). invasion of blood vessels into the mineralized cartilage, osteoprogenitors and osteoclasts are brought into replace the cartilaginous template with bone tissue though their bone formation and resorption function (Karsenty \& Wagner 2002, Long \& Ornitz 2013).

The terminal hypertrophic chondrocytes will finally undergo apoptosis accompanied by resorption of mineralized cartilage and vascularization (Shapiro et al. 2005). The proliferation and differentiation of chondrocytes drives the elongation of skeletal elements (Long \& Ornitz 2013).

Endochondral ossification is spatially and temporally governed by integrated networks of molecules, especially the lineage-specific transcription factors such as SOX9 and RUNX2 (Karsenty et al. 2009). SOX9 plays an essential role in multiple steps of chondrocyte differentiation together with L-SOX5 and SOX6 (Chang et al. 2004). SOX9 is highly expressed in the mesenchymal condensations and then in proliferative chondrocytes, with a maximal expression in prehypertrophic chondrocytes, but abruptly disappears from the hypertrophic zone (Chang et al. 2004, Hattori et al. 2010). SOX9-expressing precursors during mouse embryogenesis give rise to all osteo-chondroprogenitor cells (Dell'Accio et al. 2001). SOX9 activates multiple genes expressed in proliferating chondrocytes, including the extracellular matrix (ECM) genes COL2A1 (van Rhijn et al. 2002, Trebicz-Geffen et al. 2003) and Aggrecan (Keats et al. 2003). Some studies have indicated that SOX9 expressed in the prehypertrophic zone may inhibit COL10A1 expression through MEF2C, a MADS box transcription factor (Leung et al. 2011). SOX9 has been proposed to be

Published by Bioscientifica Ltd 
necessary for chondrocyte survival and hypertrophy to delay terminal maturation (Cowan et al. 2003, Hattori et al. 2010). Furthermore, SOX9 can inhibit the expression of RUNX2, a runt-domain transcription factor, and induce the degradation of RUNX2 in chondrocytes (Mangion et al. 1999, Amizuka et al. 2000). RUNX2 plays a pivotal role in the promotion of chondrocyte hypertrophy. RUNX2 is initially expressed in the chondrogenic mesenchyme, subsequent to SOX9 (Dell'Accio et al. 2001). RUNX2 is restrictedly located to the perichondrial cells and osteoblasts after cartilage anlage is formed, and then is expressed in the prehypertrophic and early hypertrophic chondrocytes (Provot \& Schipani 2005). Several lines of evidence have supported the role of RUNX2 as an important positive regulator of the hypertrophic program (Vidrich et al. 2009, Hafner et al. 2010, Shinde et al. 2013). RUNX2 initiates chondrocyte hypertrophy, and loss of RUNX2 leads to severely delayed chondrocyte maturation in developing bones (Dooley et al. 2007, Shinde et al. 2013). Furthermore, RUNX2 expressed in the perichondrium can regulate the perichondrial expression of fibroblast growth factor 18 (FGF18) to modulate growth plate development through indirect mechanisms (Park et al. 2007). RUNX2 stimulates the expression of IHH and VEGF (Tanaka et al. 2006) in hypertrophic chondrocytes (Gunhaga et al. 2003). RUNX2 is also well known for its essential role in osteoblast differentiation (Fortin et al. 2005, Shroff 2013) and its promotion of expression of osteoblast-specific genes (Ogata et al. 2008, Lin \& Melero-Martin 2012).

The development of the growth plate is tightly regulated by various systemic and local molecules such as growth hormone, thyroid hormone, bone morphogenetic proteins (BMPs), Wnt/ $\beta$-catenin, FGFs, and transforming and growth factor (TGF) $\beta$ (Long \& Ornitz 2013). Previous work revealed that parathyroid hormonerelated protein (PTHRP)/IHH feedback loop plays a major role during chondrogenesis (Kobayashi et al. 2002). PTHRP is synthesized in the periarticular region, activates the PTH/PTHRP receptor (PTR) expressed in prehypertrophic zone, then stimulates cell proliferation, and delays the hypertrophic differentiation (Eswarakumar et al. 2005). Prehypertrophic and hypertrophic chondrocytes release IHH, which stimulates chondrocyte proliferation and PTHRP synthesis. PTHRP suppresses chondrocyte maturation. IHH also determines the location of bone collar formation (Chung et al. 2001). Many other pathways, including FGF signaling, can regulate chondrocyte proliferation and maturation indirectly through their interactions with the PTHRP/IHH feedback loop (Grimsrud et al. 2001,
Minina et al. 2001, Guo et al. 2009, Yano et al. 2013). Any disturbances of these signaling pathways will interfere with growth plate development, and finally result in a variety of skeletal dysplasias (Maes et al. 2010, Kerkhofs et al. 2012, Michigami 2013).

\section{A brief introduction to FGFs/FGF receptors signaling}

In addition to PTHRP/IHH feedback loop, FGF signaling also remarkably regulate growth plate development (Amizuka et al. 2004). FGFs are a family of 22 members binding to their high-affinity receptors, FGF receptor 1-4 (FGFR1-4). FGFs mediate their cellular responses through distinct binding affinity with individual FGFRs. FGFs can be divided into three subfamilies: canonical FGFs (FGF1-10, 16-18, 20, 22), hormone-like FGFs (FGF15/19, 21,23), and intracellular FGFs (FGF11-14) (Itoh \& Ornitz 2008). Like other receptor tyrosine kinases (RTKs), a prototypical FGFR contains an extracellular ligandbinding domain, a hydrophobic transmembrane region, and an intracellular tyrosine kinase domain (Burdan $e t$ al. 2009). FGFRs have two major FGFR isoforms generated by alternative splicing of the third extracellular immunoglobulin loop in FGFR transcripts, IIIb and IIIc (Gong (2014)). FGFs bind to the extracellular domain of FGFRs, cause receptor dimerization, and induce phosphorylation of tyrosine residues in their intracellular domain. The activated FGFR recruits target proteins to its cytoplasmic tail and modifies them mainly by phosphorylation (Powers et al. 2000). There are several important downstream pathways of FGF signaling, such as the STAT, MAPK, phosphatidyl inositol-3-kinase (PI3K)/AKT, and phospholipase C-gamma (PLC $\gamma$ )/protein kinase C (PKC) pathways. These pathways are associated with the phosphorylation of specific tyrosine residues and regulate a variety of cell functions, such as cell proliferation, differentiation, survival, and matrix production (Powers et al. 2000, Dailey et al. 2005).

\section{Expression of FGFs and FGFRs during skeletal development}

The spatiotemporal expression patterns of FGFs and FGFRs have been characterized (Fig. 2; Ornitz 2005, Du et al. 2012, Long \& Ornitz 2013).

FGFR1 is expressed diffusely in mesenchyme of limb buds and somites, in prehypertrophic, and hypertrophic chondrocytes, and perichondrium of the epiphyseal growth plates, and more in differentiated osteoblasts, as

Published by Bioscientifica Ltd 

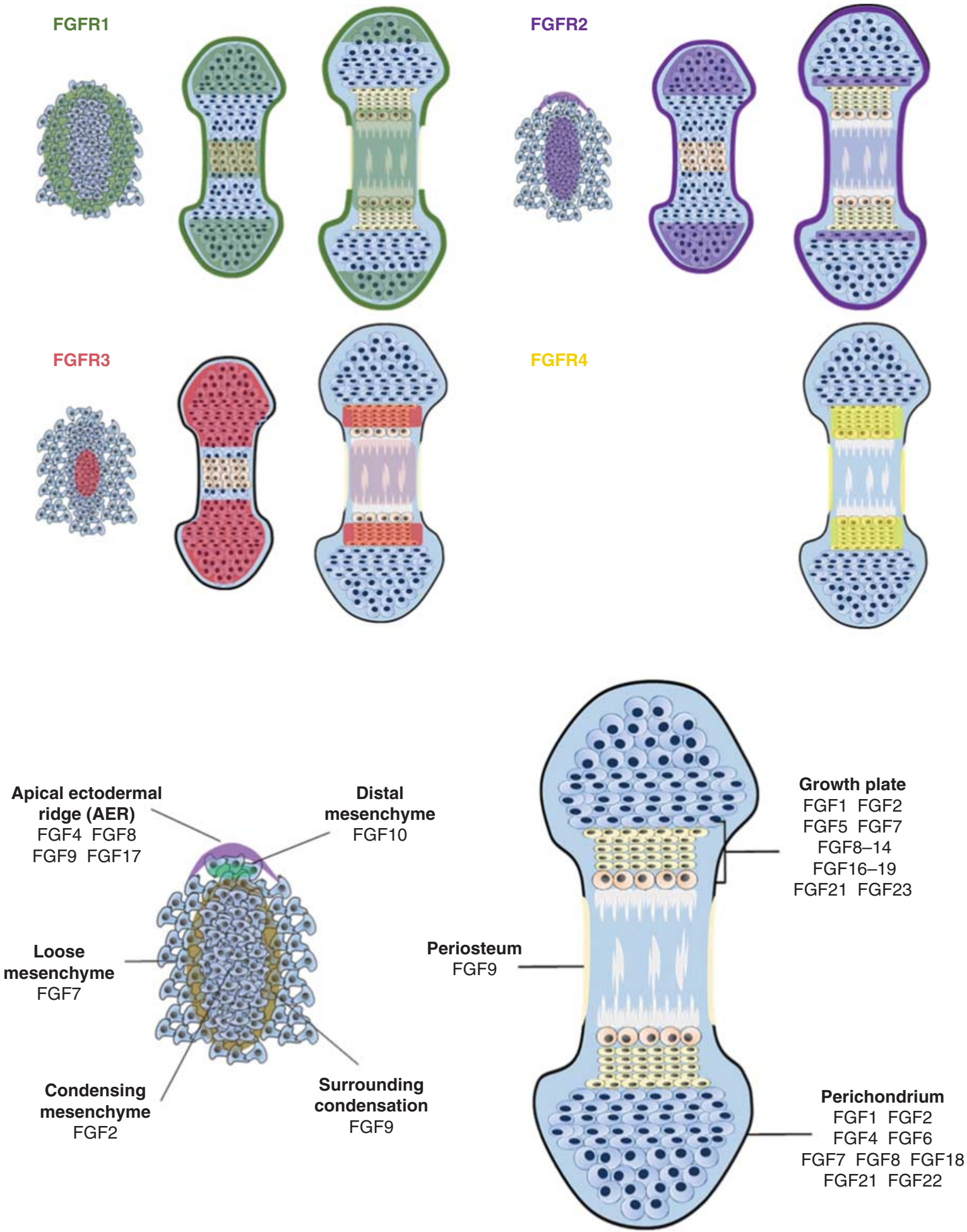

\section{Figure 2}

Expression of FGFs/FGFRs during endochondral bone formation. Expression patterns of FGFRs are shown in the upper panel and FGFs in the lower panel. The cells are color coded for FGFRs (Liu et al. 2002, Ohbayashi et al. 2002, Minina et al. 2005, Hung et al. 2007, Yu \& Ornitz 2008).

http://jme.endocrinology-journals.org DOI: $10.1530 / J M E-14-0012$
() 2014 Society for Endocrinology Printed in Great Britain
Published by Bioscientifica Ltd 
well as osteocytes (Xiao et al. 2004, Jacob et al. 2006, Lazarus et al. 2007, Kyono et al. 2012). FGFR2 has been detected in condensing mesenchyme of early limb bud (Peters et al. 1992, Orr-Urtreger et al. 1993, Delezoide et al. 1998) and appears as the first marker of prechondrogenic condensation. FGFR2 is predominantly localized to perichondrial and periosteal tissues and expressed weakly in endosteum and trabecular bone during later limb development (Yu et al. 2003). In addition, expression of FGFR 2 has been observed in cartilage, especially in the resting zone (Rice et al. 2000, 2003, Wilkie 2005, Lazarus et al. 2007, Yin et al. 2008). In cranial sutures, FGFR2 has been detected in osteoprogenitor cells and osteoblasts (Iseki et al. 1999). FGFR3 expression has been observed in chondrocytes located in the central core of the mesenchymal condensation (Peters et al. 1993). As the epiphyseal growth plate is formed, FGFR3 is expressed in all chondrocytes except hypertrophic chondrocytes (Peters et al. 1993, Szebenyi et al. 1995, Colvin et al. 1996, Delezoide et al. 1998, Ornitz 2005, Jacob et al. 2006). Expression of FGFR3 has also been found in osteoblasts and osteocytes (Valverde-Franco et al. 2004, Su et al. 2010). In addition, FGFR3 has been detected in head periostea and sutural osteogenic fronts (Delezoide et al. 1998, Rice et al. 2000). Very low amounts of FGFR4 are present in the osteoblasts of calvarial bone and resting and proliferative zones of growth plates (Partanen et al. 1991, Cool et al. 2002, Lazarus et al. 2007).

FGF1 has been found in proliferating and hypertrophic chondrocytes (Krejci et al. 2007). FGF2 is expressed in limb bud, chondrocytes, and osteoblasts (Fallon et al. 1994, Montero et al. 2000, Lazarus et al. 2007, Fei \& Hurley 2012). Four FGFs are expressed in the mouse apical ectodermal ridge (AER): FGF4, FGF8, FGF9, and FGF17 (Moon et al. 2000, Mariani et al. 2008). FGF1, 2, 4, 8, 9, and particularly FGF18, which is produced by the perichondrium, bind to and activate FGFR3 (Moon \& Capecchi 2000). FGF9 is expressed in the mesenchyme surrounding the cartilaginous condensations, chondrocytes, and primary spongiosa as well as perichondrium/periosteum (Hung et al. 2007). FGF10 is found in the presumptive limb field (Ohuchi et al. 1997, Martin 1998, Xu et al. 1998), and its expression persists in the mesenchyme under AER after initial limb bud formation ( $\mathrm{Xu}$ et al. 1998). FGF18 is expressed apparently in the perichondrium, mesenchymal cells, and osteoblasts during bone development (Liu et al. 2002, Ohbayashi et al. 2002). FGF1, 2, 6, 7, 9, 18, 21, and 22 are expressed in perichondrium, while FGF2, 7, 18, and 22 are expressed in growth plates in rats (Lazarus et al. 2007). The transcripts for FGF1, 2, 5, 8-14, 16-19, and 21 have also been found in growth plates, while only FGF1,
2, 17, and 19 are detectable at the protein level (Krejci et al. 2007). FGF23 is mainly synthesized by osteocytes and osteoblasts (Bonewald \& Wacker 2013). Recently, FGF23 expression has been found in resting and hypertrophic chondrocytes (Raimann et al. 2013).

\section{Roles of FGFs/FGFRs in skeletal development: clues from human genetic skeletal syndromes and mouse models}

Numerous studies have demonstrated the important role of FGFs/FGFRs in bone development. Mutations in FGFs/FGFRs are responsible for a diverse group of skeletal genetic disorders. For FGFRs, mutations in FGFR1 and FGFR2 mainly cause syndromes involving craniosynostoses, whereas the dwarfing syndromes are largely associated with FGFR3 mutations.

A gain-of-function (GOF) missense mutation in FGFR1 (Pro252Arg) causes Pfeiffer syndrome (PS) which result in broad toes and split thumbs (Muenke et al. 1994). Several activating FGFR1 mutations, such as N330I and C379R, cause osteoglophonic dysplasia (OD), and the patients displayed craniosynostosis, prominent supraorbital ridges, and depressed nasal bridge, as well as rhizomelic dwarfism and non-ossifying bone lesions (White et al. 2005). In contrast, loss-of-function (LOF) mutations in FGFR1 such as C277Y, R622X, P772S, G97D, and A167S are responsible for autosomal-dominant Kallmann syndrome (KS), characterized by hypogonadism and anosmia. Some KS patients have skeletal abnormalities, i.e. butterfly vertebra and oligodactyly of the feet, indicating that FGFR1 can regulate endochondral ossification (Jarzabek et al. 2012). GOF mutations in FGFR2 can cause multiple types of craniosynostoses, such as Apert syndrome (AS), Crouzon syndrome (CS), and PS, as well as Beare-Stevenson cutis gyrata syndrome (BSS) (Wilkie 2005, Cunningham et al. 2007, Park et al. 2012, Sharma et al. 2012, Wilkinson et al. 2012). Several de novo FGFR2 mutations have been demonstrated to be responsible for a perinatal lethal skeletal dysplasia designated as bent bone dysplasia (BBD)-FGFR2 type (Merrill et al. 2012). GOF mutations in FGFR3 lead to hypochondroplasia $(\mathrm{HCH})$, achondroplasia $(\mathrm{ACH})$, and thanatophoric dysplasia (TD) with dysregulated endochondral ossification (He et al. 2012, Krejci 2014). GOF mutations in FGFR3 have also been found to cause premature suture fusion, leading to craniosynostoses. FGFR3, p.Ala334Thr, has been found to be responsible for mild craniosynostosis (Barroso et al. 2011). FGFR3 A391E mutation in the transmembrane region is responsible for Crouzon dermoskeletal syndrome (Wilkes et al. 1996).

Published by Bioscientifica Ltd 
FGFR3 P250R and P252R mutations cause Muenke syndrome (Meyers et al. 1995, Wilkes et al. 1996, Muenke et al. 1997, Arnaud-Lopez et al. 2007, Agochukwu et al. 2012). Furthermore, some TD patients show joint fusion and craniosynostoses (Tavormina et al. 1995). A p.R621H substitution in the tyrosine kinase domain, leading to partial loss of FGFR3 function, causes camptodactyly, tall stature, and hearing loss (CATSHL) syndrome (Toydemir et al. 2006). Until now, no mutation in FGFR4 has been found to be responsible for genetic skeletal disorders in humans (Valverde-Franco et al. 2004, Marie et al. 2005).

Mutations of FGFs have also been found in multiple genetic skeletal disorders. Genotyping of SNPs in FGF genes revealed associations between cleft palate and SNPs in FGF3, FGF7, FGF10, FGF18, and FGFR1 (Riley et al. 2007). In humans, constitutionally increased dosage of the $F G F 3$ and FGF4 genes plays an important role in the onset of craniosynostosis (Grillo et al. 2014). FGF8 mutations may be associated with craniofacial defects and acrocephalosyndactyly (Whitehead et al. 2004, Bouillon et al. 2008). A mutation (S99N) in FGF9 is associated with multiple synostosis syndromes (SYNS) in humans (Wu et al. 2009). LOF mutations in FGF10 cause lacrimo-auriculo-dento-digital syndrome (Milunsky et al. 2006, Rohmann et al. 2006, Shams et al. 2007), which is an autosomal-dominant multiple congenital anomaly disorder characterized by lacrimal duct aplasia, malformed ears and deafness, dental, and digital anomalies. FGF10 is also thought to be a candidate gene for cleft palate (King et al. 1991, Perry et al. 1991, Schwartz et al. 1992, Turnquist et al. 1992). FGF23 plays a crucial role in phosphate homeostasis (Yu \& White 2005, Fukumoto \& Yamashita 2007). X-linked hypophosphatemic rickets (XLH) and autosomal recessive hypophosphatemic rickets/osteomalacia are caused by mutations in the phosphate-regulating endopeptidase (PHEX) and dentin matrix protein 1 (DMP1) genes respectively and patients show elevated FGF23 levels (Jonsson et al. 2003, Fukumoto \& Yamashita 2007, Yoshiko et al. 2007). Excess levels of FGF23 in patients with these hypophosphatemic disorders lead to renal phosphate wasting and suppression of circulating $1,25(\mathrm{OH})_{2} \mathrm{D}_{3}$ levels (Wohrle et al. 2013). Autosomal dominant hypophosphatemic rickets (ADHR) are caused by missense mutations in the FGF23 gene, leading to the resistance of the mutant FGF23 to degradation (White et al. 2000). Furthermore, patients afflicted with tumor-induced osteomalacia (Shimada et al. 2001) also show elevated FGF23 serum levels.

Accumulating evidence from mouse model studies (Table 1) and cell lines have confirmed the roles of FGFs/FGFRs and their underlying mechanisms in skeletal development and human skeletal dysplasias.
Fgfr1 P252R transgenic mice mimicking human PS exhibit premature suture closure and de novo digit I polydactyly in the hind limb with upregulation of Wnt5a and downregulation of $D k k 1$, which encodes a secreted Wnt inhibitor (Hajihosseini et al. 2004). FGFR1 exists in hypertrophic chondrocytes and perichondrium of the epiphyseal growth plates, but knowledge regarding its role in growth plate development is limited. Zhou found that FGFs/FGFR1 signals cause increased expression of RUNX2 and lead to premature fusion of cranial sutures in mice carrying the Fgfr1 P250R mutation (Zhou et al. 2000). Fgfr1-deficient $\left(F g f r 1^{-/-}\right)$mouse embryos display severe growth retardation and die before or during gastrulation (Deng et al. 1994, Yamaguchi et al. 1994). We found that disruption of Fgfr1 in adult mouse articular chondrocytes (via Col2a1Cre) inhibits the progression of cartilage degeneration in aging-related and induced osteoarthritis (Weng et al. 2012). Jacob et al. (2006) revealed that FGFR1 inhibits proliferation of mesenchymal progenitor cells but promotes their differentiation into preosteoblasts and suppresses the maturation and mineralization of osteoblasts. Our preliminary data indicate that conditional deletion of FGFR1 in osteoblasts leads to an increase in bone mass in adult and aging mice (Nan Su \& Lin Chen 2013 unpublished observations). In addition, FGFR1 may positively regulate osteoclasts (Lu et al. 2009). FGFR1 also participates in phosphorus metabolism through regulating the transcription of FGF23 (Wohrle et al. 2011, 2013, Donate-Correa et al. 2012).

Mice mimicking human AS show premature closure of cranial base synchondroses and retarded endochondral bone growth with expanded resting zone and narrowed proliferating and hypertrophic zones in growth plates (Chen et al. 2003). The P253R mutation in FGFR2 leads to retardation of the growth of long bones by directly affecting endochondral ossification (Yin et al. 2008). BBD patients have growth plates with smaller hypertrophic chondrocytes and thicker hypercellular periosteum. The chondrocytes from patients have reduced responsiveness to extracellular FGF18 and deficient plasma-membrane localization of FGFR2 (Merrill et al. 2012). In zebrafish, fgfr2 is required for mesenchyme condensation and later chondrogenic differentiation (Larbuisson et al. 2013). Targeted disruption of Fgfr2IIIC leads to narrowing of the proliferative and hypertrophic chondrocyte zones with decreased IHH and PTHRP expression and retarded ossification with a decrease in the transcription of secreted phosphoprotein 1 and RUNX2 (Eswarakumar et al. 2002). As FGFR2 is predominantly expressed in osteogenic cells, a lot of studies have been carried out in order to understand

Published by Bioscientifica Ltd 


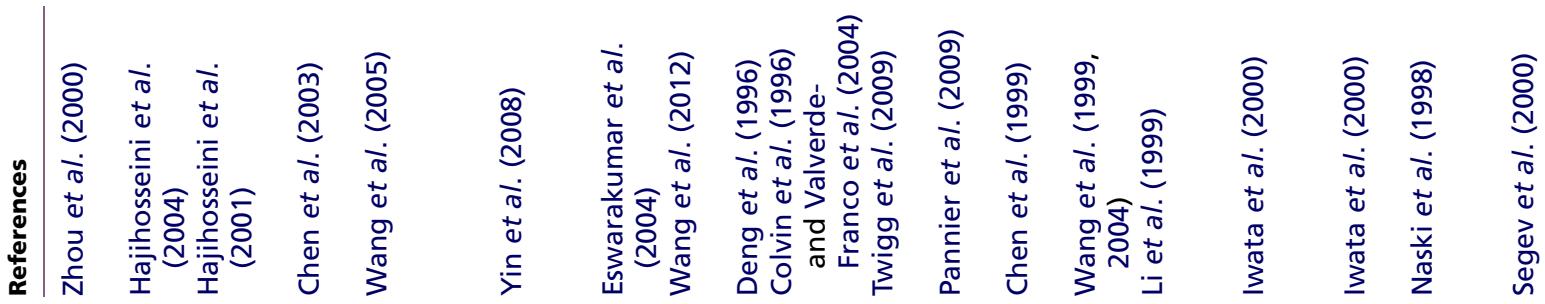

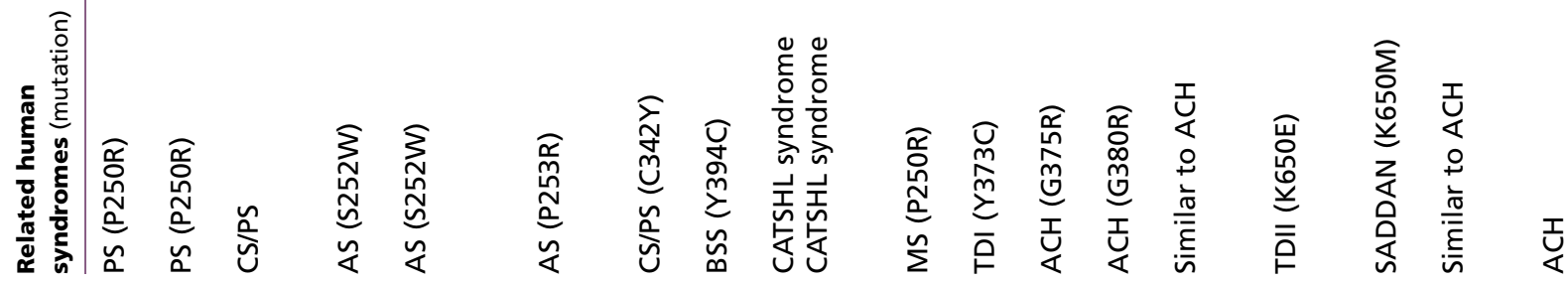

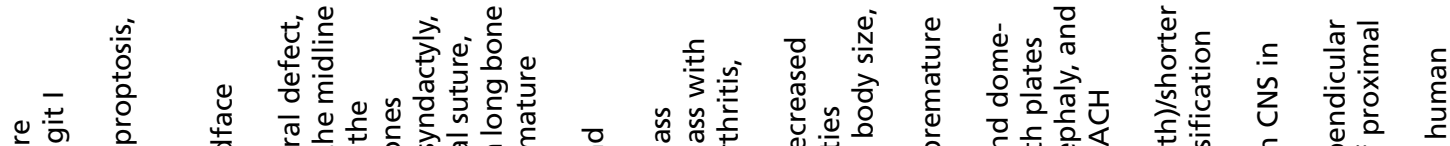

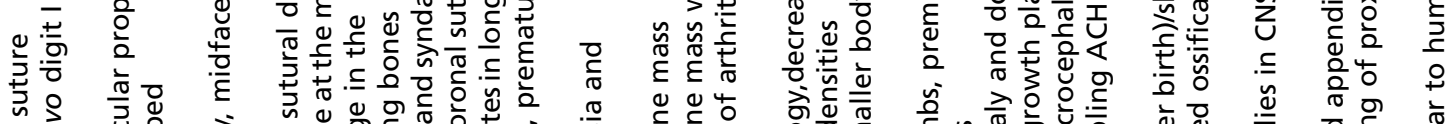

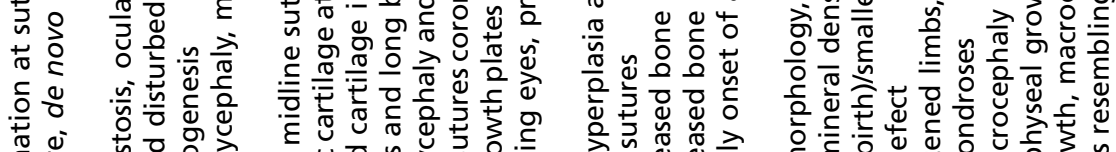

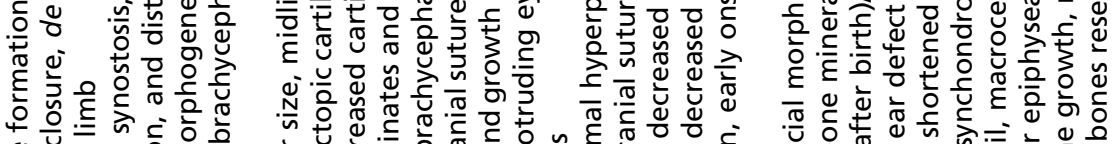

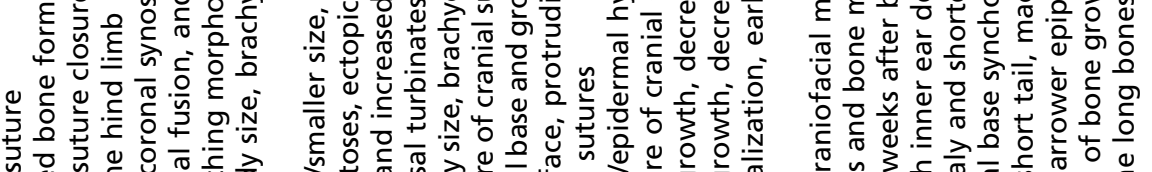

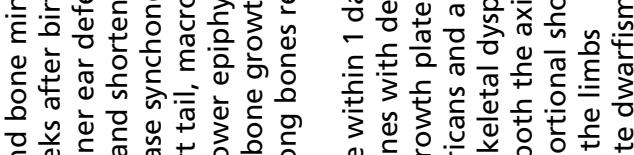

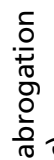<smiles>c1ccc2ccccc2c1</smiles>

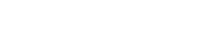

$$
\text { 旁 }
$$

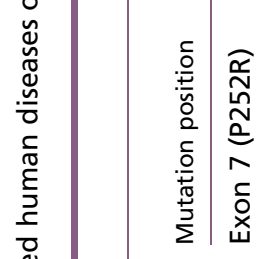

$\frac{+}{0}$

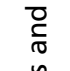

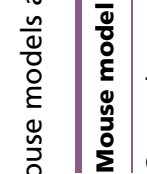

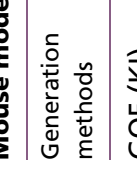

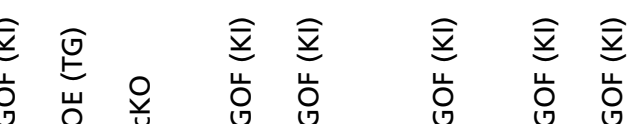

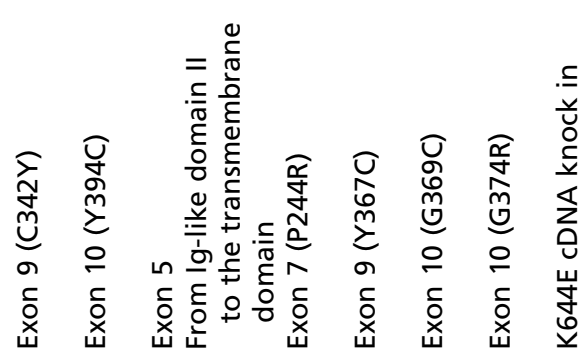

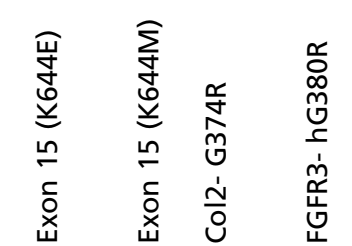

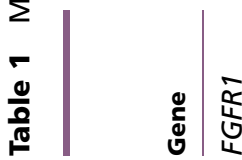

选

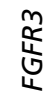




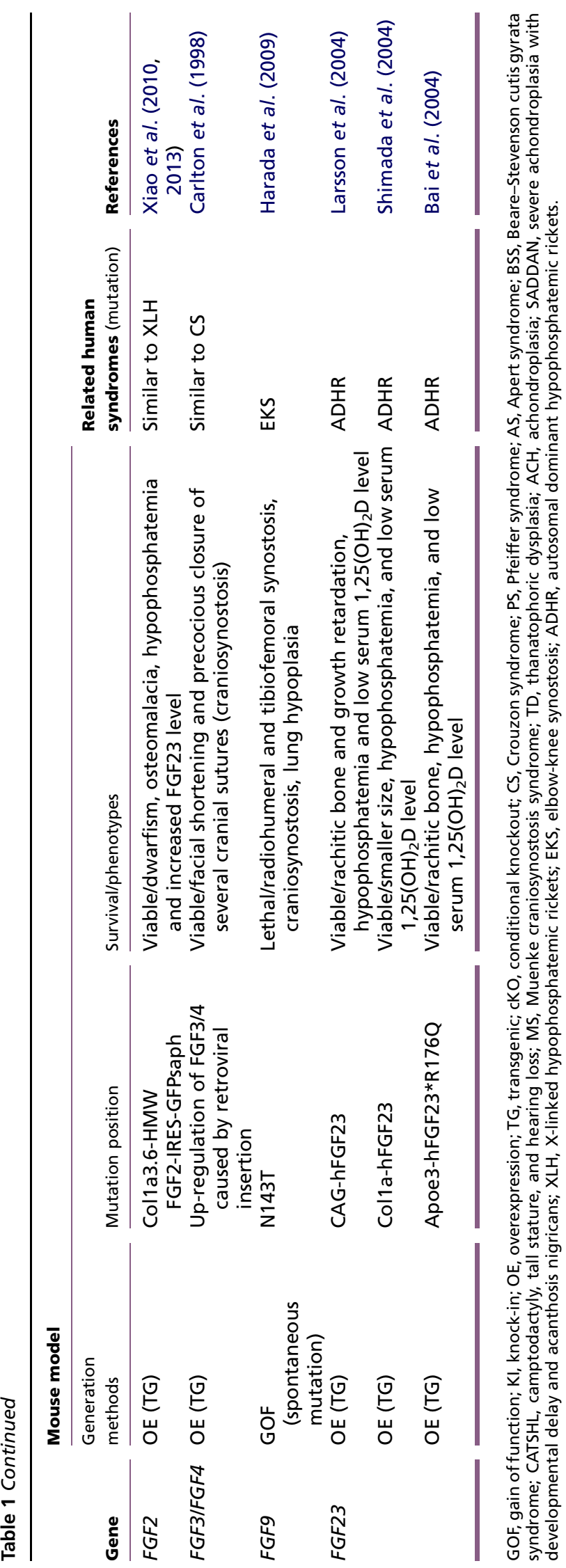

http://jme.endocrinology-journals.org DOI: 10.1530/JME-14-0012 (c) 2014 Society for Endocrinology Printed in Great Britain its role and the underlying mechanisms in osteogenesis. FGFR2 is mainly involved in the regulation of the proliferation of osteogenic cells in sutures (Iseki et al. 1997, 1999). Results from some studies have indicated that FGFs/FGFR2 signaling positively regulates the differentiation of osteoblasts (Lomri et al. 1998, 2001, Lemonnier et al. 2001). The FGFR2 S252W mutation results in advanced proliferation and differentiation of osteoblastic cells, as well as increased apoptosis of osteogenic cells in mice (Chen et al. 2003, Wang et al. 2005). On the other hand, results from several studies have indicated that FGFs/FGFR2 signaling blocks the differentiation and mineralization and induces apoptosis of osteoblasts (Mansukhani et al. 2000, 2005). Furthermore, the FGFR2 C342Y mutation (the equivalent mutation in humans causes CS and PS) promotes aberrant cranial osteoblast differentiation and apoptosis, and the mutant bone marrow stromal cells have an autonomous defect in osteoblast differentiation and bone mineralization (Feteih et al. 1990, Eswarakumar et al. 2004). Studies of the Fgfr2 W290R mouse model mimicking CS revealed that W290R is a LOF mutation (Gong 2012). Heterozygotic abrogation of Fgfr2IIIc in mice leads to a splicing switch, resulting in a GOF mutation, which causes a phenotype similar to those of some AS and PS patients (Hajihosseini et al. 2001). Due to the embryonic lethality of conventional $F g f r 2$ knockout in mice, conditional knockout of Fgfr2 has been adopted to explore the role of FGFR2 in osteogenesis. Yu and colleagues found that conditional deletion of Fgfr2 in mesenchyme (via dermo1-Cre) of mice causes dwarfism and decreased bone mineral density with reduction in diaphyseal thickness, indicating that FGFR2 is required for mineral deposition (Yu et al. 2003). Results from a study by Wang and colleagues indicate that FGFR2 may influence transdifferentiation. Cultured cells isolated from the limbs of Fgfr2 S252W mice can differentiate into chondrocytes in osteogenic medium, and these mice have enhanced chondrogenic markers and ectopic cartilage formation at sagittal sutures (Wang et al. 2005). In addition, FGFR1/2 have been found to regulate the markers of mesenchymal stem cells (MSC) and are important in the maintenance of MSC stem cell properties (Coutu et al. 2011).

Mice carrying mutations of $F g f r 3$, mimicking human ACH exhibit smaller body size, dome-shaped skulls, and shortened long bones with disorganized chondrocyte columns in growth plates (Naski et al. 1998, Chen et al. 1999, Wang et al. 1999, 2004, Segev et al. 2000, Ornitz \& Marie 2002). Mice mimicking human TDII-carrying the Fgfr3 K644E mutation exhibit enhanced chondrocyte proliferation during the early embryonic skeletal

Published by Bioscientifica Ltd 
development and reduced hypertrophic chondrocytes throughout the embryonic stage (Li et al. 1999, Iwata et al. 2000). The Fgfr3 K644M mutation causes severe dwarfism in mice (Iwata et al. 2001) and the Y367C mutation causes chondrodysplasia, hearing loss, and inner ear defects in mice (Pannier et al. 2009). The above data indicate that FGFR3 negatively regulates the proliferation and differentiation of chondrocytes. Results from several studies have indicated that FGFR3 signaling inhibits chondrocyte proliferation through STAT1 signaling by inducing the expression of P21 (Su etal. 1997, Li etal. 1999, Sahni etal. 1999, Murakami etal. 2004), and promotes chondrocyte terminal hypertrophic differentiation partially through MAPK (Minina et al. 2002, Dailey et al. 2003). The cellular mechanisms underlying the growth arrest of chondrocytes induced by FGFR3 remain unclear. Chen et al. (1999) found that ACH mice exhibits increased staining for cell-cycle inhibitors including P16 and P19 in growth plates. Further studies have shown that P21 and P27 are accumulated upon FGF2 treatment and that the expression of P21 is increased in the chondrocytes of achondroplasic children (Krejci et al. 2004, Parafioriti et al. 2009). These results indicate that upregulation of cell-cycle inhibitors contributes to the growth arrest of chondrocytes. Some results indicate that FGFR3 downregulates the IHH signaling pathway in both growth plate chondrocytes and perichondrium (Naski et al. 1998, Iwata et al. 2000). JAK/STAT has been found to mediate the downregulation of PTH/PTHRP signaling by FGFR3 (Chen et al. 2001, Li et al. 2010). FGFR3 inhibits the proliferation of chondrocytes by downregulating telomerase reverse transcriptase expression and reducing telomerase activity (Mendelsohn \& Larrick 2012). Results from some studies indicate that FGFR3 can induce chondrocyte apoptosis partially through the PLC $\gamma$ STAT1 pathway (Yamanaka et al. 2003, L'Hote \& Knowles 2005, Harada et al. 2007, Krejci et al. 2010, Elo et al. 2012). Henderson found that the expression of G380R FGFR3 in CFK2 chondrocytic cells inhibits cell growth but protects them from apoptosis caused by serum starvation (Henderson et al. 2000). Krejci demonstrated that activation of endogenous $F g f r 3$ in rat chondrosarcoma (RCS) cells (proliferating chondrocytes derived from RCS) leads to a reversible premature senescence phenotype (Krejci et al. 2010). There are also some disputes about the role of FGFR3 in hypertrophic differentiation of chondrocytes. Chen and colleagues found that FGFR3 inhibits the hypertrophic differentiation of chondrocytes in cultured metatarsals (Chen et al. 1999), while Minina et al. (2002) revealed that FGFs/FGFR3 signaling accelerates the onset and the pace of hypertrophic differentiation of chondrocytes in limb culture system. Conversely, Fgfr3 deficiency in mice causes increased bone length due to increased chondrocyte hypertrophy (Colvin et al. 1996, Deng et al. 1996). FGFs/FGFR3 signaling decreases the chondrocyte ECM. On the one hand, FGFR3 signaling inhibits synthesis of chondrocyte ECM through inhibition of the expression of the matrix proteins such as aggrecan and collagen2 (Krejci et al. 2004, Foldynova-Trantirkova et al. 2012). On the other hand, FGFR3 can promote the degradation of ECM via upregulating the expression, release, and activation of several MMPs, including MMP3, 9, 10, and 13 (Krejci et al. 2005). Fgfr3-deficient mice show early onset of arthritis, and disruption of $F g f r 3$ in cartilage at the adult stage leads to early onset of arthritis with elevated expression of MMP13 (Valverde-Franco et al. 2006). FGF18/FGFR3 signaling is involved in autophagy of chondrocytes (Bernheim \& Benchetrit 2011). FGFs/FGFR3 signaling inhibits C-type natriuretic peptide (CNP) signaling, while CNP antagonizes the activation of the MAPK (Ozasa et al. 2005). Snail1 has been found to be a downstream molecule of FGFs/FGFR3 signaling, regulating both STAT and MAPK in chondrocytes (de Frutos et al. 2007). Results obtained by Shung and colleagues revealed that dysregulation of SOX9 and $\beta$-catenin levels and their activity in growth plates might be an important underlying mechanism in skeletal dysplasias caused by mutations in FGFR3 (Shung et al. 2012). Furthermore, FGFR3 also regulates osteogenesis (Marie et al. 2012). FGFR3 P244R mice mimicking human Muenke craniosynostosis syndrome show rounded skulls, shortened snouts and decreased cortical thickness and bone mineral densities in long bones, indicating that FGFR3 participates in the regulation of osteogenesis (Twigg et al. 2009). Su et al. (2010), found that FGFR3 inhibits the proliferation of bone marrow stromal cells, but promotes their osteogenic differentiation. Activation of FGFR3 in cartilage induces premature synchondrosis closure and enhances osteoblast differentiation around synchondroses through upregulation of expression of BMPs and down-regulation of expression of BMP antagonists, Noggin, Chordin, and Gremlin expression via MAPK pathway (Matsushita et al. 2009). Mugniery and colleagues found that activating FGFR3 signaling pathways may affect trabecular bone formation by a paracrine mechanism and that FGFR3 has a direct effect on osteoblasts (Mugniery et al. 2012). Conditional deletion of FGFR3 in osteoblasts (via OC-Cre) leads to impaired bone formation and remodeling, indicating the vital role of FGFR3 in the differentiation and function of osteoblasts (Nan Su \& Lin Chen 2013 unpublished observations). Both FGFR3 deletion and activation lead to defective bone mineralization and osteopenia with changed osteoclastic activity, indicating an indirect effect of FGFR3 on osteoclasts

Published by Bioscientifica Ltd 
through its regulation of osteoblasts (Valverde-Franco et al. 2004, Su et al. 2010).

Fgfr4-deficient mice are developmentally normal, while $F g f r 3 / F g f r 4$ double-null mice show pronounced dwarfism (Weinstein et al. 1998). Further studies revealed that $F g f r 3 / F g f r 4$ double-null mice have lower serum phosphorus levels and elevated FGF23 and 1,25(OH) vitamin $\mathrm{D}_{3}$ levels compared with WT mice (Gattineni et al. 2011). The supraphysiological levels FGF23 and $1,25(\mathrm{OH})_{2-}$ vitamin $\mathrm{D}_{3}$ may be responsible for the growth retardation of Fgfr3/Fgfr 4 double-null mice (Larsson et al. 2004, Kawai et al. 2013, Bach et al. 2014). Results also indicated that FGFR1, FGFR3, and FGFR4 function cooperatively to mediate the effects of FGF23 on kidney, and that loss of FGFR function leads to feedback stimulation of FGF23 expression in bone (Li et al. 2011a, Gattineni et al. 2014).

Fgf2 transgenic mice (TgFGF2), such as the dwarf, show shortened bone and moderate macrocephaly and defective bone formation and mineralization (Coffin et al. 1995). Fgf2 deficiency in mice leads to osteopenia in the adult stage, without observable abnormalities during development (Montero et al. 2000). Results from multiple studies have indicated the role of ectogenic FGF2 in regulation of bone formation (Mayahara et al. 1993, Nakamura et al. 1995). Sobue et al. (2005) proposed that FGF2 negatively regulates postnatal bone growth and remodeling resulting from targeted overexpression of $F g f 2$ in the chondrocytes and osteoblasts of mice. FGF2 also participates in bone homeostasis and phosphate metabolism. Targeted overexpression of high molecular weight (hmw, 21 and $22 \mathrm{kDa}$ ) isoforms of FGF2 in osteoblasts of mice results in dwarfism, decreased BMD, increased FGF23 level, hypophosphatemia, and rickets/osteomalacia, which is similar to XLH (Xiao et al. 2010, 2013). Targeted overexpression of low molecular weight isoform (lmw, $18 \mathrm{kDa}$ ) of FGF2 in osteoblasts leads to increased BMD, bone mass, and enhanced mineralization, resulting from the reduced expression of the secreted frizzled receptor 1 , a Wnt antagonist (Xiao et al. 2013). In contrast to $T g F g f 2 l m w$ mice, $F \& 2^{l m w-1-}$ mice show markedly reduced BMD and impaired mineralization (Xiao et al. 2009). Interestingly, endogenous FGF2 has been proved to be required for bone formation and osteoclastogenesis either under basal conditions or after treatment with PTH and BMP2 (Okada et al. 2003, Hurley et al. 2006, Sabbieti et al. 2009). Activating transcription factor 4 (ATF4) (Fei et al. 2011) and prostaglandin $F_{2 \alpha}$ also induce osteoblast proliferation and differentiation via endogenous FGF2 (Sabbieti et al. 2010). Insertional mutations at the $\mathrm{Fgf3/Fgf4}$ locus can lead to craniofacial dysmorphology in mice (Carlton et al. 1998). FGF6 has been considered to be a regulator of bone metabolism as shown by its activity in both osteoblasts and osteoclasts in vitro (Huch et al. 2003). Conditional disruption of $F g f 8$ in the forelimbs leads to aplasia of radius and/or humerus and digit disorders, but mouse limbs lacking other AerFgfs, such as $F g f 4, F g f 9$, and $F g f 17$, show normal skeletal patterns (Moon \& Capecchi 2000). Fff8 can effectively predetermine the osteogenic differentiation of mouse bone marrow stromal cells and C2C12 cells and increase bone formation in vitro (Valta et al. 2006, Omoteyama \& Takagi 2009). In another study, Fgf8 has been found to promote proliferation of primary rat osteogenic cells and inhibit osteogenic differentiation and mineralization (Lin et al. 2009). FGF8 has also been shown to be as a regulator of ectopic cartilage formation by breast cancer cells (Valta et al. 2006). FGF8 can promote the degradation of cartilage leading to exacerbation of osteoarthritis (Uchii et al. 2008). The Fgf9 N143T mutation in mice causes elbow-knee synostosis (EKS) (Murakami et al. 2002, Harada et al. 2009). Fff9 promotes chondrocyte hypertrophy and vascularization of the growth plates (Hung et al. 2007). Overexpression of $F g f 9$ in mouse chondrocytes causes rhizomelia similar to $\mathrm{ACH}$, with disturbed proliferation and terminal differentiation in growth plate chondrocytes (Garofalo et al. 1999). Fof18 deficiency in mice leads to increased chondrocyte proliferation and delayed long bone ossification and calvarial suture closure with reduced expression of the osteogenic markers such as osteopontin and osteocalcin. These results indicate that FGF18 is involved in chondrogenesis of growth plate and osteogenesis in cortical and trabecular bone, as well as the osteogenesis in the calvarial bone (Liu et al. 2002, Ohbayashi et al. 2002). Increased expression of FGF21 during food restriction causes growth attenuation via antagonizing the stimulatory effects of growth hormone on chondrogenesis, while high concentrations of FGF21 may directly suppress chondrocyte proliferation and differentiation in growth plates (Wu et al. 2012). FGF21 can enhance the osteogenic activity of BMP2 via upregulating the Smad signaling pathway in C2C12 cells (Ishida \& Haudenschild 2013). FGF23 is a member of the endocrine FGFs and is mainly produced by bone cells, klotho, a single-pass transmembrane protein, is required for the binding of FGF23 to its receptors (Yu et al. 2005). FGF23 targets the kidney to suppress $1,25(\mathrm{OH})_{2}$ vitamin $\mathrm{D}_{3}$ synthesis and accelerate phosphate excretion into the urine. Patients with elevated FGF23 have similar clinical phenotypes and serum biochemical profiles, such as short stature, rickets, osteomalacia, lower extremity deformities,

Published by Bioscientifica Ltd 
and a low serum phosphate concentration. Transgenic mice overexpressing Fgf23 have phenotypes similar to the clinical characteristics of ADHR, TIO and XLH (Bai et al. 2004, Larsson et al. 2004, Shimada et al. 2004, Yu \& White 2005). Conversely, mice with deletions in Fgf23 show hyperphosphatemia, ectopic mineralization, and poorly formed skeletons with an extremely low PTH level and an elevated $1,25(\mathrm{OH})_{2}$ vitamin $\mathrm{D}_{3}$ level (Liu et al. 2006). $\mathrm{Fg} 23$ decreases the expression of renal NaPi-2a and NaPi-2c and induces hypophosphatemia predominantly via Fgfr 1 (Gattineni et al. 2009). Results from further studies indicate that supraphysiological FGF23 and soluble $\alpha$-klotho may directly affect bone through their suppression on IHH expression, and administration of IHH protein partially rescued the suppressive effect of FGF23 on metatarsal growth (Shalhoub et al. 2011, Kawai et al. 2013).

Although there are controversies about the role of FGFs/FGFRs signaling in skeletal cells, the results described above indicate that FGF signaling regulates skeletal development and homeostasis by affecting all skeletal cells, including MSCs, chondrocytes, osteoblasts, osteocytes, and osteoclasts. FGF signaling affects skeletal cells through their downstream signaling pathways and their interactions with other molecules controlling skeletal development and homeostasis, including IHH, BMPs, PTHRP, WNTS, SOXS, and RUNX2 (Fig. 3; Murakami et al. 2004, Dailey et al. 2005, Mansukhani et al. 2005, Ambrosetti et al. 2008, Yin et al. 2008, Su et al. 2010, FoldynovaTrantirkova et al. 2012, Krejci et al. 2012).

\section{Promising therapeutic methods to alleviate the skeletal phenotypes resulting from dysfunction FGFs/FGFRs}

A better understanding of the underlying mechanisms involved in the skeletal diseases mentioned earlier will allow the development of novel biologic therapies for these diseases. Accumulated studies have been carried out to alleviate the skeletal phenotypes caused by dysfunctional FGFs/FGFRs signaling (Table 2). For GOF mutations,

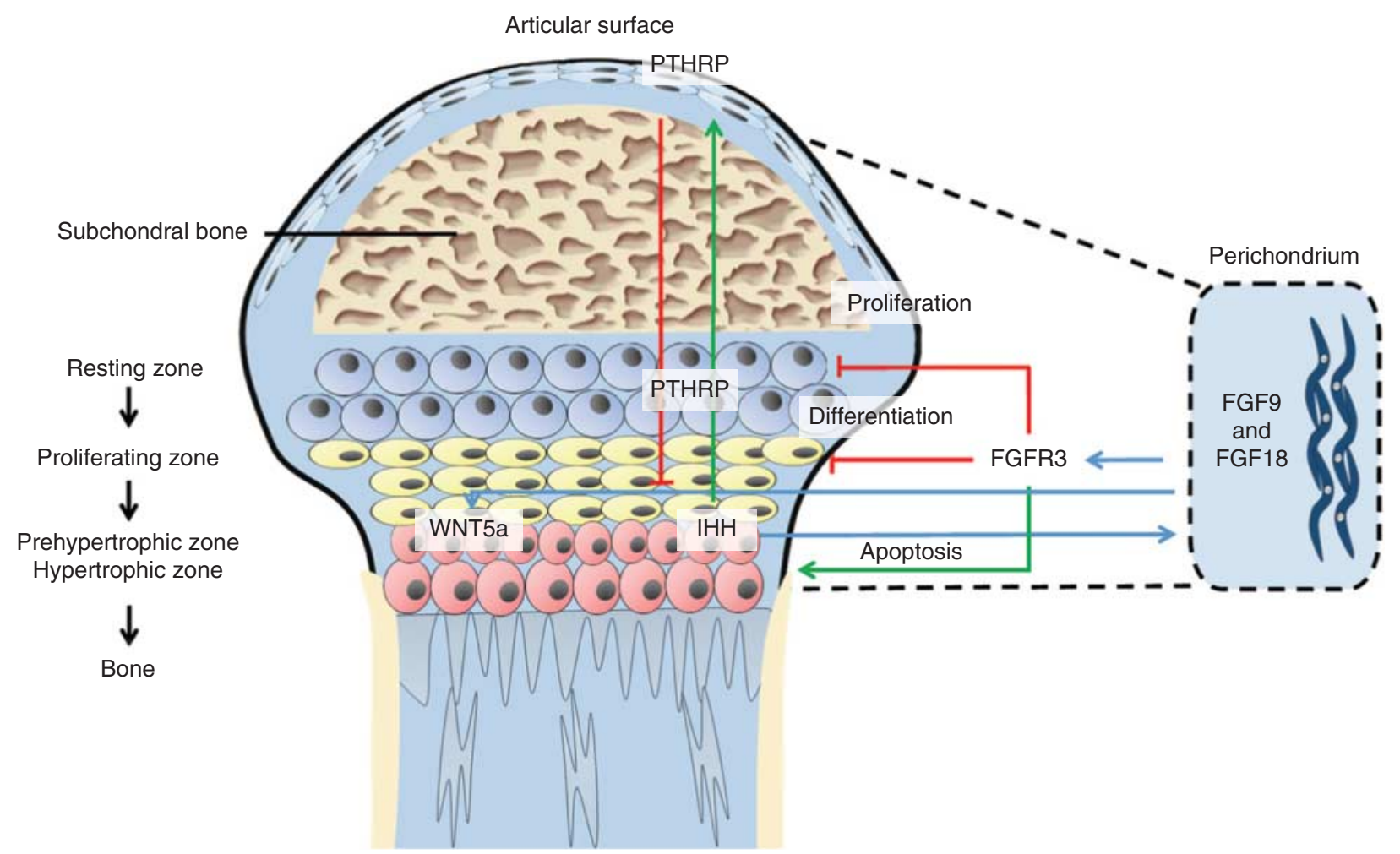

Figure 3

Signals regulating growth plate development. The growth plate is divided into four distinct zones. IHH and PTHRP coordinate chondrocyte proliferation and differentiation through a negative-feedback mechanism. Prehypertrophic and hypertrophic chondrocytes release $\mathrm{IHH}$, which stimulates chondrocyte proliferation and PTHRP synthesis. PTHRP synthesized in periarticular region/resting zone before/after the second ossification http://jme.endocrinology-journals.org DOI: 10.1530/JME-14-0012
() 2014 Society for Endocrinology Printed in Great Britain center formation in turn suppresses chondrocyte differentiation associated with $\mathrm{IHH}$ expression. FGF9/18 from the perichondrium suppresses chondrocyte proliferation and maturation through FGFR3 in the growth plate during embryonic development and postnatal bone growth. A number of WNTs expressed by growth plate chondrocytes stimulate the proliferation of chrondrocytes (data from Long \& Ornitz (2013)).

Published by Bioscientifica Ltd 
the major strategy is to reduce their excessive activities, subsequently alleviating the impaired cell functions, while, for LOF mutations or deficiency, supplementation of related factors may be helpful.

To prevent excessive intracellular signaling and rescue the symptoms of FGFs/FGFRs-related genetic disorders, a variety of molecules targeting FGFRs or their tyrosine kinase activity were used. A soluble form of the Apert mutant, FGFR2 (sFGFR2IIIcS252W), lacking the transmembrane and cytoplasmic domains, as a decoy receptor, can compete for ligand binding with FGFRs and enhance osteoblastic differentiation of the MG63 osteosarcoma cell line transfected with the Apert mutant (Tanimoto et al. 2004). Furthermore, calvarial osteoblasts derived from sFGFR2IIICS252W mice show lower activation of MEK, ERK, and p38 pathways than that in osteoblasts from Apert mice (Suzuki et al. 2012). Recently, Morita and colleagues found that sFGFR2IIIcS252W may partially prevent craniosynostosis in the Apert mouse model (Morita et al. 2014). RNA interference targeting the Fgfr 2 S252W can completely rescue the Apert-like phenotype in mice (Shukla et al. 2007). There are also an increasing number of works related to Fgfr3-related skeleton disorders. A31, a novel tyrosine kinase inhibitor, can restore normal expression of cell cycle regulators (proliferating cell nuclear antigen, KI67, cyclin D1, and p57) and allow pre-hypertrophic chondrocytes to properly differentiate into hypertrophic chondrocytes in cultured femurs from ACH mice (Jonquoy et al. 2012). We have described the utility of a novel FGFR3-binding peptide for rescuing the lethal phenotype and partially restoring the structural distortion of growth plates of mice carrying the TDII mutation (Jin et al. 2012a). Garcia et al. (2013) developed a recombinant protein therapeutic approach using a soluble form of human FGFR3 (sFGFR3), as a decoy receptor, and found that it could rescue the phenotypes of $\mathrm{ACH}$ transgenic mice with no toxicity. Another approach to target FGFR3 directly is use of an anti-FGFR3 antibody. To date, antibodies targeting FGFR3 have been developed and shown to exhibit antitumor activity for FGFR3associated multiple myeloma and bladder carcinoma (Trudel et al. 2006, Hadari \& Schlessinger 2009, Qing et al. 2009, Kamath et al. 2012). But antibody may carry a risk of an antibody-dependent cell cytotoxic reaction (Yamamoto et al. 2010), which prevents its use in ACH.

So far, several approaches aiming to reduce excessive activation of FGF signaling by targeting its downstream pathways have been proposed. Treating Fgfr2 S252W mice mimicking AS in humans with an inhibitor of MEK1/2, U0126, can effectively alleviate craniosynostoses (Shukla et al. 2007). An inhibitor of $\mathrm{p} 38$, SB203580, can ameliorate skin and skull abnormalities in Beare-Stevenson mice (Wang et al. 2012). Deletion of STAT1 in Ach mice can restore the reduced chondrocyte proliferation but cannot rescue the Ach phenotype (Murakami et al. 2004). ERK has been found to be responsible for the retarded growth of long bones and premature fusion of the synchondroses caused by aberrant FGFR3 expression (Nowroozi et al. 2005, Matsushita et al. 2009). Sebastian and colleagues found that genetic inactivation of ERK1 and ERK2 in chondrocytes can enlarge the spinal canal and promote bone growth (Sebastian et al. 2011). MEK inhibitors PD0325901 and AZD6244 are under clinical investigation for cancer treatment, they can expand the hypertrophic zone of the growth plates in cultured bone (El-Hoss et al. 2014). These results indicate that inhibition of ERK signaling may enlarge the narrowing of the spinal canal, alleviating the neurological complications of $\mathrm{ACH}$. As overexpression of SNAIL1 in mice causes an ACH-like phenotype, and SNAIL1 acts as a transcriptional factor for FGFR3 signaling, targeted inhibition of SNAIL1 may be a therapeutic method for FGFR3-related disorders (Martinez-Frias et al. 2010). CNP rescues the shortened bones due to $\mathrm{ACH}$ by ameliorating the decreased synthesis of ECM in chondrocytes through inhibition of MAPKs. Targeted overexpression of CNP in cartilage or systemic administration of CNP can rescue the disturbed growth of ACH mice (Yasoda \& Nakao 2010). A 39-amino-acid CNP analog (BMN 111) mimicking CNP pharmacologically has an extended half-life. Treating Ach mice with BMN 111 leads to the attenuation of the dwarfism phenotype (Lorget et al. 2012). Weaker PTH/PTR expression was found in the growth plates of Ach mice, we for the first time, to our knowledge, found that PTHRP can partially reverse the growth retardation of cultured long bone rudiments from ACH mice (Chen et al. 2001). Ueda and colleagues found that the PTH1-34 treatment may counterbalance the effects of FGFR3 with $A C H$ mutation on long bone development (Ueda et al. 2007). We further found that intermittent PTH1-34 injection rescues the retarded skeletal development and postnatal lethality of mice mimicking human $\mathrm{ACH}$ and TD dysplasia through the promotion of chondrocyte proliferation (Xie et al. 2012). Minina and colleagues revealed that BMP signaling improves the narrowed proliferative and hypertrophic zone in growth plates of ACH mice (Minina et al. 2002). Recently, Matsushita found that Meclozine, a histamine $\mathrm{H} 1$ antagonist, facilitates the proliferation and differentiation of chondrocytes by attenuating excessively activated FGFR3 signaling possibly mediated

Published by Bioscientifica Ltd 
Table 2 Promising therapeutic methods to alleviate the skeleton phenotypes resulting from FGFs-FGFRs related mutations

\begin{tabular}{|c|c|c|c|c|c|}
\hline Gene & Targets & Molecules/methods & Materials & Effects & References \\
\hline \multirow[t]{6}{*}{ FGFR2 } & Itself & sFGFR2IIICS252W & $\begin{array}{l}\text { MG63 osteosar- } \\
\text { coma cells }\end{array}$ & $\begin{array}{l}\text { Binds to FGFs acts as a decoy } \\
\text { receptor }\end{array}$ & $\begin{array}{l}\text { Tanimoto et al. } \\
\text { (2004) }\end{array}$ \\
\hline & & & $\begin{array}{l}\text { Calvarial osteo- } \\
\text { blasts }\end{array}$ & $\begin{array}{l}\text { Downregulates the activity of MEK, } \\
\text { ERK, and p38 pathways }\end{array}$ & Suzuki et al. (2012) \\
\hline & & & Transgenic mice & $\begin{array}{l}\text { Prevents craniosynostosis in the } \\
\text { Apert mouse }\end{array}$ & Morita et al. (2014) \\
\hline & & FGFR2 S252W RNAi & Transgenic mice & Rescues Apert-like syndrome & Shukla et al. (2007) \\
\hline & $\begin{array}{l}\text { Downstream } \\
\text { signaling }\end{array}$ & $\begin{array}{l}\text { MEK inhibitor, } \\
\text { U0126 }\end{array}$ & Apert mice & Rescues craniosynostosis & Wang et al. (2012) \\
\hline & & $\begin{array}{l}\text { P38 inhibitor, } \\
\text { SB203580 }\end{array}$ & $\begin{array}{l}\text { Beare-Stevenson } \\
\text { mice }\end{array}$ & $\begin{array}{l}\text { Ameliorates skin and skull } \\
\text { abnormalities }\end{array}$ & Shukla et al. (2007) \\
\hline \multirow[t]{15}{*}{ FGFR3 } & $\begin{array}{l}\text { Itself or } \\
\quad \text { tyrosine kinase }\end{array}$ & $\begin{array}{l}\text { Tyrosine kinase } \\
\text { inhibitor A31 }\end{array}$ & $\begin{array}{l}\text { Femur from } \mathrm{ACH} \\
\text { mice }\end{array}$ & $\begin{array}{l}\text { Restores the expression of } \\
\text { cell cycle regulator } \\
\text { Rescues differentiation of } \\
\text { chondrocytes }\end{array}$ & $\begin{array}{l}\text { Jonquoy et al. } \\
\text { (2012) }\end{array}$ \\
\hline & & Peptide P3 & Cell lines & $\begin{array}{l}\text { Inhibits the tyrosine kinase activity } \\
\text { of FGFR3 }\end{array}$ & Jin et al. (2012a) \\
\hline & & & TDII mice & $\begin{array}{l}\text { Reverses the neonatal lethality of } \\
\text { Td2 mice }\end{array}$ & \\
\hline & & sFGFR3 & $\begin{array}{l}\text { Cell lines } \\
\mathrm{ACH} \text { mice }\end{array}$ & $\begin{array}{l}\text { Binds to FGFs as a decoy receptor } \\
\text { Rescues the phenotypes of Ach mice }\end{array}$ & Garcia et al. (2013) \\
\hline & $\begin{array}{l}\text { Downstream } \\
\text { signaling }\end{array}$ & Deletion STAT1 & $\mathrm{ACH}$ mice & $\begin{array}{l}\text { Ameliorates the reduced } \\
\text { chondrocyte proliferation }\end{array}$ & $\begin{array}{l}\text { Murakami et al. } \\
\text { (2004) }\end{array}$ \\
\hline & & $\begin{array}{l}\text { Inactivation of } \\
\text { ERK1 and ERK2 }\end{array}$ & $\mathrm{ACH}$ mice & $\begin{array}{l}\text { Enlarges the spinal canal and } \\
\text { promotes bone growth }\end{array}$ & $\begin{array}{l}\text { Sebastian et al. } \\
\text { (2011) }\end{array}$ \\
\hline & & $\begin{array}{l}\text { MEK inhibitors } \\
\text { PD0325901 and } \\
\text { AZD6244 }\end{array}$ & $\begin{array}{l}\text { Osteoblasts and } \\
\text { osteoclasts }\end{array}$ & $\begin{array}{l}\text { Promotes bone formation and } \\
\text { inhibits bone resorption }\end{array}$ & El-Hoss et al. (2014) \\
\hline & & & Mice & $\begin{array}{l}\text { Expands the hypertrophic zones of } \\
\text { the growth plates }\end{array}$ & \\
\hline & & $\begin{array}{l}\text { MAPKs antagonist, } \\
\text { CNP }\end{array}$ & $\mathrm{ACH}$ mice & $\begin{array}{l}\text { Rescues the impaired skeletal } \\
\text { growth of Ach mice }\end{array}$ & $\begin{array}{l}\text { Yasoda \& Nakao } \\
\quad(2010)\end{array}$ \\
\hline & & $\begin{array}{l}\text { CNP analog BMN } \\
111\end{array}$ & $\mathrm{ACH}$ mice & $\begin{array}{l}\text { Attenuates the dwarfism pheno- } \\
\text { type of Ach mice }\end{array}$ & Lorget et al. (2012) \\
\hline & $\begin{array}{l}\text { Other } \\
\quad \text { signaling }\end{array}$ & PTHrP & $\begin{array}{l}\text { Metatarsal bone } \\
\text { from } \mathrm{ACH} \text { mice }\end{array}$ & $\begin{array}{l}\text { Partially reverses the retarded long } \\
\text { bone growth }\end{array}$ & Chen et al. (2001) \\
\hline & & PTH1-34 & $\begin{array}{l}\text { Femur from Ach } \\
\text { mice }\end{array}$ & Promotes bone growth of Ach mice & Ueda et al. (2007) \\
\hline & & PTH1-34 & $\mathrm{ACH}$ and TDII mice & $\begin{array}{l}\text { Rescues the retarded skeletal } \\
\text { development }\end{array}$ & Xie et al. (2012) \\
\hline & & BMP & $\begin{array}{l}\text { Limbs from } \mathrm{ACH} \\
\text { mice }\end{array}$ & $\begin{array}{l}\text { Rescues the reduced domains of } \\
\text { proliferating and hypertrophic } \\
\text { chondrocyte }\end{array}$ & Minina et al. (2002) \\
\hline & & $\begin{array}{l}\text { Histamine } \mathrm{H} 1 \\
\text { antagonist, } \\
\text { meclozine }\end{array}$ & $\begin{array}{l}\text { Cell lines and bone } \\
\text { explant }\end{array}$ & $\begin{array}{l}\text { Facillitates the proliferation and } \\
\text { differentiation of } \\
\text { chondrocytes }\end{array}$ & $\begin{array}{l}\text { Matsushita et al. } \\
\text { (2013) }\end{array}$ \\
\hline \multirow[t]{2}{*}{ FGF23 } & Itself & $\begin{array}{l}\text { Recombinant } \\
\text { FGF23 }\end{array}$ & WT mice & $\begin{array}{l}\text { Induces hypophosphatemia with } \\
\text { increased renal phosphate } \\
\text { clearance }\end{array}$ & $\begin{array}{l}\text { Shimada et al. } \\
\text { (2004) }\end{array}$ \\
\hline & & $\begin{array}{l}\text { Neutralizing } \\
\text { anti-FGF23 MABs }\end{array}$ & Hyp mice & $\begin{array}{l}\text { Ameliorates the rachitic bone } \\
\text { phenotypes of Hyp mice }\end{array}$ & Aono et al. (2011) \\
\hline
\end{tabular}

by downregulation of ERK phosphorylation (Matsushita et al. 2013). Shung and colleagues revealed that dysregulation of SOX9 and $\beta$-catenin levels and activity in growth plates might be an important underlying mechanism in skeletal dysplasia caused by mutations in FGFR3 (Shung et al. 2012) which indicates that regulating SOX9 or $\beta$-catenin could be a therapy for these diseases.

http://jme.endocrinology-journals.org DOI: 10.1530/JME-14-0012

C) 2014 Society for Endocrinology Printed in Great Britain
Either GOF- or LOF of FGF23 can cause abnormal growth plate development and several metabolic bone diseases (Lu \& Feng 2011). Novel therapies, inhibiting the excessive activity of FGF23 or replacement therapy with recombinant FGF23, may be beneficial for those patients with abnormal growth plate development and several metabolic bone diseases. Aono et al. $(2009,2011)$ showed

Published by Bioscientifica Ltd 
that applications of neutralizing anti-FGF23 MABs can ameliorate the rachitic bone phenotypes of Hyp mice mimicking $X L H$ in humans (e.g., impaired longitudinal elongation, defective mineralization, and abnormal cartilage development). Administration of either recombinant WT Fgf23 or the ADHR mutant form of Fgf23 to WT mice induces hypophosphatemia with increased renal phosphate clearance (Shimada et al. 2004, Shimada \& Fukumoto 2012).

More studies are needed before clinical application, through close collaboration between laboratory scientist and clinicians. Encouragingly, BMN 111 developed by BioMarin Pharmaceuticals is now being evaluated in a Phase 2 pediatric study in children with $\mathrm{ACH}$ (http://www. bmrn.com).

\section{Perspectives}

Although we have made extensive progresses in understanding the roles of FGF signaling in the skeleton, especially in growth plate development and diseases during the last 20 years by using genetically modified mouse models and patients with mutations in FGFs and FGFRs, we are still far from fully understanding their underlying mechanisms, which prevents us from finding effective cures for those FGFs/FGFRs-related genetic diseases and injuries. Much work need to be done before can develop successful treatments. We here list several important issues that need further study.

Each individual FGF and FGFR has its own spatiotemporal distribution and unique roles in skeletal development and diseases as mentioned earlier (Ornitz \& Itoh 2001, Marie et al. 2012). These results are mainly derived from animal models, especially from mice, which are quite different from human beings. For example, FGF18 is expressed in the adjacent perichondrium but not in the cartilage of mice, acting as a physiological ligand for FGFR3 and regulating FGFR3 activity in growth plate chondrocytes and FGFR2 in perichondrium to coordinate chondrogenesis and osteogenesis in mice (Liu et al. 2002, 2007). However, in humans FGF18 is not found in perichondrium or cartilage, and FGFs secreted from perichondrium are unlikely to efficiently diffuse into the whole growth plate chondrocytes, indicating that other FGFs but not FGF18 expressed in human growth plates such as FGF1, FGF2, and FGF17 may be involved in the regulation of chondrocyte proliferation and differentiation (Krejci et al. 2007, Foldynova-Trantirkova et al. 2012). The accurate spatiotemporal expressions of FGFs/FGFRs, especially in the case of diseases, need to be further studied. Using conventional or inducible transgenic Cre mice with genes driven by endogenous FGFs/FGFRs promoters, together with reporter mice, it should be possible to explore the expression patterns of FGFs/FGFRs during skeletal development and genetic or acquired diseases/injuries. Expression patterns founded in animal models need to be further checked in clinical specimens. In addition, there are still some FGFs, such as FGF21 and FGF23, that have been found to be expressed in growth plates (Krejci et al. 2007, Raimann et al. 2013), but for which their function in growth plate development and damage is still largely unknown. In vivo models with spatially and temporally modified expression of FGFs, and FGFRs in mice or other animals need to be generated to explore the roles of each individual FGF and FGFR in growth plate development and diseases/injuries.

Although there are accumulating studies about the role of FGFs/FGFRs signaling in growth plate development, we still have very limited information about how FGFs, and FGFRs themselves are regulated by other molecules. We need to know how FGFs, and FGFRs are transcriptionally regulated, whether they are also subjected to epigenetic modification, such as regulation by methylation, non-coding RNA (microRNA and long non-coding RNA). Post-transcriptional modifications (PTM) such as phosphorylation, acetylation, and small ubiquitin-related protein modification are also very important in regulating protein activity; however, we know very little about the PTM of FGFs and FGFRs. Stability of proteins is essential for the maintenance of protein function. Overexpression of Sprouty 1 in chondrocytes results in decreased FGFR2 ubiquitination, increased FGFR2 stability, and sustained ERK activation (Yang et al. 2008). The detailed mechanisms underlying the degradation of FGFRs after ligand binding are poorly known.

FGF signals are transduced by a series of downstream signaling molecules typically including but not limited to FRS2-RAS-MAPK, PI3K-AKT, DAG-PKC, and PLC $\gamma$ (Chung et al. 1998). Presently, we do not know whether all FGFs, and FGFRs share similar downstream signaling molecules, or whether each individual FGF and FGFR, in different cell lineages or development stages, exert its functions through a distinctive combination of different downstream molecules. For example, are the differential roles of FGFR3 and FGFR1 in growth plate chondrocytes just the result of the distinct spatiotemporal expression patterns of FGFR1, and FGFR3? Or also related to the distinct downstream signaling molecules of FGFR1, and FGFR3? One important phenomenon in this field is the inhibition of AKT activity and chondrocyte proliferation by FGFR3,

Published by Bioscientifica Ltd 
which normally acts as a mitogenic signal in other cell lineages. We need to clarify why just $F G F R 3$, but not other FGFRs, can downregulate AKT activity and cause inhibited chondrocyte proliferation and differentiation (Raucci et al. 2004, Priore et al. 2006). Whether there is interplay or redundancy among FGFs and FGFRs during growth plate development and diseases also needs further study. Like other signaling pathways, FGF signaling also need coordination with other pathways to regulate cartilage development and diseases (Jin et al. 2012b, Marie et al. 2012). For example, in early mouse embryos, FGFs and $B M P s$ are integrated to regulate limb-bud overgrowth (Verheyden \& Sun 2008). The balance between BMP and FGF signaling pathway determines the rate of chondrocyte proliferation during chondrogenesis (Minina et al. 2002). Some data indicates that FGFs and BMPs can regulate the expression and stability of their downstream signaling components mutually (Matsushita et al. 2009, Retting et al. 2009). We recently found that FGFR3 can downregulate protein levels of BMPR1a in a proteasomedependent way (Qi et al. 2014). However, it is not clear how these two important signaling pathways regulate each other in processes involved in the development and damage of growth plates. Many pathways such as WNT/ $\beta$-catenin, TGF- $\beta$, and PTH play essential roles in growth plate development and diseases and the interplay among FGF signaling, and these important signaling pathways occur in multiple cell types of the skeleton during development and disease development. Clarifying the interactions among FGF signaling and other signaling pathways in skeleton cells will deepen our understanding of the mechanisms underlying growth plate development and diseases, which will provide us with the molecular bases to search for therapies for growth plate maldevelopment and diseases/injuries. Different mutations in the same FGFRs cause distinct clinical syndromes, for example A391E in FGFR3 causes CDS, while G380R leads to ACH, P250R in FGFR 1 causes PS, but C379R cause OD syndrome, which indicates that mutations in FGFRs do not just cause just GOF or LOF, studying these mutations may lead to identification of novel functions of FGFRs, but we know little about this at present.

Other RTK-related molecules such as VEGF has been found to have intracrine functions (Lee et al. 2007). The traffic of FGFs/FGFRs inside cells may also play an important role in exerting the physiological and pathophysiologic functions of FGFs/FGFRs (Ueno et al. 2011, Coleman et al. 2014). We need to study the trafficing of FGFs/FGFRs, especially the nuclear FGFs/FGFRs, and their role in growth plate development and diseases.
The development of growth plates involves a series of coordinated cellular events including the proliferation and chondrogenic/osteogenic differentiation of mesenchymal cells, and the hypertrophic differentiation, mineralization, and apoptosis of chondrocytes. To date, the detailed effect of individual FGFs and FGFRs on each of these developmental stages of chondrocytes is not fully understood. For example, there are disputes about the role of FGFR3 in chondrocyte proliferation, differentiation, and apoptosis, a similar dispute also exists about the role of FGFR2 in osteoblast differentiation and apoptosis. Furthermore, we have found that prehypertrophic chondrocytes in Ach mice express osteocalcin, a marker for mature osteoblasts (Chen et al. 1999), but whether activating FGFR3 causes the transdifferentiation of prehypertrophic chondrocytes into osteoblasts has still not been elucidated. The activation FGFR2 has been found to cause chondrogenic differentiation of cultured cells in osteogenic medium, collected from the long bone of Apert mice (Wang et al. 2005). All these results indicate that FGF signaling may also change the fates of chondrocytes and osteoblasts. We need to confirm this and explore the underlying mechanisms. Luckily, emerging new techniques will certainly help with exploration of the mechanisms of growth plate development. These new techniques include, but are not limited to, genomics technology, generation of novel Cre/Cre-ERT2 mouse models (inducible, split Cre-ERT, etc.) and endogenous FGFs/FGFRs reporter mice, cell lineage tracing, in vivo dynamic imaging, cell ablation, etc. Also important is cloning of more specific markers for distinct developmental stages of chondrocytes, which could be used to generate more stage-specific Cre mouse strains and to classify developing chondrocytes into more narrow but distinct stages. In addition, emerging clues indicate that FGF signaling regulates many important cellular events such as autophagy, endoplasmic reticulum stress, and cell senescence under both physiological and pathological conditions, but whether FGF signaling also regulate these events in skeletal development and diseases and the underlying mechanisms are still unknown.

Numerous variants clustered in genomic loci including FGF18, FGFR3, and FGFR4 have been found to affect human height (Lango Allen et al. 2010, Lui et al. 2012). FGFR1 has been found to be associated with normal variation in craniofacial shape (Coussens \& van Daal 2005). More clinical studies such as Genome Wide Association Studies (GWAS) and exon sequencing need to be carried out to explore the relationships between single-nucleotide polymorphisms in FGF and FGFR genes and skeletal phenotypes including body height, bone shapes, and bone mineral

Published by Bioscientifica Ltd 
density, as well as to find new genetic disorders resulting from mutations in FGFs/FGFRs.

Although some drugs such as BMN111 appears to be promising for $\mathrm{ACH}$, as they are for other genetic diseases, we presently do not have effective biological treatments for almost all FGF signaling-related skeletal dysplasias. While measures such as preimplantation genetic diagnosis and prenatal screening should be taken to prevent these diseases, biological treatment of FGF-related genetic diseases is an important research field. In general, we can modulate FGF signaling at multiple levels. For GOF mutations, we can target mutant FGFs, and FGFRs at their DNA, RNA, and protein level. Genome editing is being increasingly used to correct genetic diseases (Li et al. 2011b, Ma et al. 2013), so far little similar work has been done to treat FGF-signaling-related genetic skeletal diseases. These new techniques include, but are not limited to, genome editing technology (zinc finger nuclease, transcription activator-like (TAL) effector nucleases, and CRISPR/Cas9), RNA interference, and neutralizing antibodies (Li et al. 2011b, Lokody 2014, Ochiai et al. 2014). We can also target the downstream signaling molecules such as MAPK by using CNP (Yasoda \& Nakao 2010), or we can regulate other pathways involved in regulation of growth plate development, such as PTH (Xie et al. 2012). As there are a variety of downstream molecules and related pathways regulating growth plate development, we need to screen these molecules carefully to find out which molecules and/or pathways are more suitable and practical for use to alleviate the phenotypes of those skeletal dysplasia. Also importantly, we need to test at which levels (DNA, RNA, and protein), using which strategies (e.g., CRISPR/Cas9 versus TALEN, RNAi versus antisense, neutralizing antibody versus chemical inhibitors, etc.) we can better modulate those pathways. Another important issue is to find better way to target those modulating molecules to chondrocytes, the fact that chondrocytes lack a blood supply makes this task more difficult. Finally, skeletal dysplasia is caused by maldevelopment, indicating that the timing of intervention is very important, the treatment should usually be carried out early.

\section{Declaration of interest}

The authors declare that there is no conflict of interest that could be perceived as prejudicing the impartiality of the review.

\section{Funding}

The work in Lin Chen's laboratory is supported by the Special Funds from Major State Basic Research Program of China (973 program)
(No. 2014CB942904), and grants from the National Natural Science Foundation of China (No. 81220108020, No. 81030036, No. 81170809, and No. 81301593).

\section{References}

Agochukwu NB, Solomon BD, Gropman AL \& Muenke M 2012 Epilepsy in Muenke syndrome: FGFR3-related craniosynostosis. Pediatric Neurology 47 355-361. (doi:10.1016/j.pediatrneurol.2012.07.004)

Ambrosetti D, Holmes G, Mansukhani A \& Basilico C 2008 Fibroblast growth factor signaling uses multiple mechanisms to inhibit Wntinduced transcription in osteoblasts. Molecular and Cellular Biology 28 4759-4771. (doi:10.1128/MCB.01849-07)

Amizuka N, Ozawa H \& Sasaki T 2000 The biological action of parathyroid hormone-related peptide (PTHrP) and fibroblast growth factor receptor 3 (FGFR3) on bone and cartilage. Kaibogaku Zasshi. Journal of Anatomy 75 415-425.

Amizuka N, Davidson D, Liu H, Valverde-Franco G, Chai S, Maeda T, Ozawa H, Hammond V, Ornitz DM, Goltzman D et al. 2004 Signalling by fibroblast growth factor receptor 3 and parathyroid hormone-related peptide coordinate cartilage and bone development. Bone 34 13-25. (doi:10.1016/j.bone.2003.08.009)

Aono Y, Yamazaki Y, Yasutake J, Kawata T, Hasegawa H, Urakawa I, Fujita T, Wada M, Yamashita T, Fukumoto S et al. 2009 Therapeutic effects of anti-FGF23 antibodies in hypophosphatemic rickets/osteomalacia. Journal of Bone and Mineral Research 24 1879-1888. (doi:10.1359/jbmr. 090509)

Aono Y, Hasegawa H, Yamazaki Y, Shimada T, Fujita T, Yamashita T \& Fukumoto S 2011 Anti-FGF-23 neutralizing antibodies ameliorate muscle weakness and decreased spontaneous movement of Hyp mice. Journal of Bone and Mineral Research 26 803-810. (doi:10.1002/jbmr. 275)

Arnaud-Lopez L, Fragoso R, Mantilla-Capacho J \& Barros-Nunez P 2007 Crouzon with acanthosis nigricans. Further delineation of the syndrome. Clinical Genetics 72 405-410. (doi:10.1111/j.1399-0004. 2007.00884.x)

Bach FC, Rutten KR, Hendriks K, Riemers FM, Cornelissen P, de Bruin A, Arkesteijn GJ, Wubbolts RW, Horton WA, Penning LC et al. 2014 The paracrine feedback loop between vitamin $\mathrm{D}_{3}\left(1,25(\mathrm{OH})_{2} \mathrm{D}_{3}\right)$ and PTHrP in prehypertrophic chondrocytes. Journal of Cellular Physiology [in press]. (doi:10.1002/jcp.24658)

Bai X, Miao D, Li J, Goltzman D \& Karaplis AC 2004 Transgenic mice overexpressing human fibroblast growth factor 23 (R176Q) delineate a putative role for parathyroid hormone in renal phosphate wasting disorders. Endocrinology 145 5269-5279. (doi:10.1210/en.2004-0233)

Barroso E, Perez-Carrizosa V, Garcia-Recuero I, Glucksman MJ, Wilkie AO, Garcia-Minaur S \& Heath KE 2011 Mild isolated craniosynostosis due to a novel FGFR3 mutation, p.Ala334Thr. American Journal of Medical Genetics. Part A 155A 3050-3053. (doi:10.1002/ajmg.a.34199)

Bernheim J \& Benchetrit S 2011 The potential roles of FGF23 and Klotho in the prognosis of renal and cardiovascular diseases. Nephrology, Dialysis, Transplantation 26 2433-2438. (doi:10.1093/ndt/gfr208)

Bonewald LF \& Wacker MJ 2013 FGF23 production by osteocytes. Pediatric Nephrology 28 563-568. (doi:10.1007/s00467-012-2309-3)

Bouillon R, Carmeliet G, Verlinden L, van Etten E, Verstuyf A, Luderer HF, Lieben L, Mathieu C \& Demay M 2008 Vitamin D and human health: lessons from vitamin D receptor null mice. Endocrine Reviews 29 726-776. (doi:10.1210/er.2008-0004)

Burdan F, Szumilo J, Korobowicz A, Farooquee R, Patel S, Patel A, Dave A, Szumilo M, Solecki M, Klepacz R et al. 2009 Morphology and physiology of the epiphyseal growth plate. Folia Histochemica et Cytobiologica $\mathbf{4 7}$ 5-16. (doi:10.2478/v10042-009-0007-1)

Carlton MB, Colledge WH \& Evans MJ 1998 Crouzon-like craniofacial dysmorphology in the mouse is caused by an insertional mutation at

Published by Bioscientifica Ltd 
the Fgf3/Fgf4 locus. Developmental Dynamics 212 242-249. (doi:10. 1002/(SICI)1097-0177(199806)212:2<242::AID-AJA8 > 3.0.CO;2-H)

Chang H, Li D, Zhuang L, Nie E, Bouman D, Stewart AK \& Chun K 2004 Detection of chromosome 13q deletions and IgH translocations in patients with multiple myeloma by FISH: comparison with karyotype analysis. Leukemia \& Lymphoma 45 965-969. (doi:10.1080/ 10428190310001638832)

Chen L, Adar R, Yang X, Monsonego EO, Li C, Hauschka PV, Yayon A \& Deng CX 1999 Gly369Cys mutation in mouse FGFR3 causes achondroplasia by affecting both chondrogenesis and osteogenesis. Journal of Clinical Investigation 104 1517-1525. (doi:10.1172/JCI6690)

Chen L, Li C, Qiao W, Xu X \& Deng C 2001 A Ser(365) $\rightarrow$ Cys mutation of fibroblast growth factor receptor 3 in mouse downregulates Ihh/PTHrP signals and causes severe achondroplasia. Human Molecular Genetics 10 457-465. (doi:10.1093/hmg/10.5.457)

Chen L, Li D, Li C, Engel A \& Deng CX 2003 A Ser252Trp [corrected] substitution in mouse fibroblast growth factor receptor 2 (Fgfr2) results in craniosynostosis. Bone 33 169-178. (doi:10.1016/S8756-3282(03) 00222-9)

Chung UI, Lanske B, Lee K, Li E \& Kronenberg H 1998 The parathyroid hormone/parathyroid hormone-related peptide receptor coordinates endochondral bone development by directly controlling chondrocyte differentiation. PNAS 95 13030-13035. (doi:10.1073/pnas.95.22. 13030)

Chung UI, Schipani E, McMahon AP \& Kronenberg HM 2001 Indian hedgehog couples chondrogenesis to osteogenesis in endochondral bone development. Journal of Clinical Investigation 107 295-304. (doi:10.1172/JCI11706)

Coffin JD, Florkiewicz RZ, Neumann J, Mort-Hopkins T, Dorn GW II, Lightfoot P, German R, Howles PN, Kier A, O'Toole BA et al. 1995 Abnormal bone growth and selective translational regulation in basic fibroblast growth factor (FGF-2) transgenic mice. Molecular Biology of the Cell 6 1861-1873. (doi:10.1091/mbc.6.12.1861)

Coleman SJ, Bruce C, Chioni AM, Kocher HM \& Grose RP 2014 The ins and outs of fibroblast growth factor receptor signalling. Clinical Science 127 217-231. (doi:10.1042/CS20140100)

Colvin JS, Bohne BA, Harding GW, McEwen DG \& Ornitz DM 1996 Skeletal overgrowth and deafness in mice lacking fibroblast growth factor receptor 3. Nature Genetics 12 390-397. (doi:10.1038/ng0496-390)

Cool S, Jackson R, Pincus P, Dickinson I \& Nurcombe V 2002 Fibroblast growth factor receptor 4 (FGFR4) expression in newborn murine calvaria and primary osteoblast cultures. International Journal of Developmental Biology 46 519-523.

Coussens AK \& van Daal A 2005 Linkage disequilibrium analysis identifies an FGFR1 haplotype-tag SNP associated with normal variation in craniofacial shape. Genomics 85 563-573. (doi:10.1016/j.ygeno.2005. 02.002)

Coutu DL, Francois M \& Galipeau J 2011 Inhibition of cellular senescence by developmentally regulated FGF receptors in mesenchymal stem cells. Blood 117 6801-6812. (doi:10.1182/blood-2010-12-321539)

Cowan CM, Quarto N, Warren SM, Salim A \& Longaker MT 2003 Age-related changes in the biomolecular mechanisms of calvarial osteoblast biology affect fibroblast growth factor-2 signaling and osteogenesis. Journal of Biological Chemistry 278 32005-32013. (doi:10.1074/jbc.M304698200)

Cunningham ML, Seto ML, Ratisoontorn C, Heike CL \& Hing AV 2007 Syndromic craniosynostosis: from history to hydrogen bonds. Orthodontics \& Craniofacial Research 10 67-81. (doi:10.1111/j.16016343.2007.00389.x)

Dailey L, Laplantine E, Priore R \& Basilico C 2003 A network of transcriptional and signaling events is activated by FGF to induce chondrocyte growth arrest and differentiation. Journal of Cell Biology 161 1053-1066. (doi:10.1083/jcb.200302075)

Dailey L, Ambrosetti D, Mansukhani A \& Basilico C 2005 Mechanisms underlying differential responses to FGF signaling. Cytokine \& Growth Factor Reviews 16 233-247. (doi:10.1016/j.cytogfr.2005.01.007)
Delezoide AL, Benoist-Lasselin C, Legeai-Mallet L, Le Merrer M, Munnich A, Vekemans M \& Bonaventure J 1998 Spatio-temporal expression of FGFR 1,2 and 3 genes during human embryo-fetal ossification. Mechanisms of Development 77 19-30. (doi:10.1016/S0925-4773(98)00133-6)

Dell'Accio F, De Bari C \& Luyten FP 2001 Molecular markers predictive of the capacity of expanded human articular chondrocytes to form stable cartilage in vivo. Arthritis and Rheumatism 44 1608-1619. (doi:10.1002/ 1529-0131(200107)44:7<1608::AID-ART284>3.0.CO;2-T)

Deng CX, Wynshaw-Boris A, Shen MM, Daugherty C, Ornitz DM \& Leder P 1994 Murine FGFR-1 is required for early postimplantation growth and axial organization. Genes and Development 8 3045-3057. (doi:10.1101/gad.8.24.3045)

Deng C, Wynshaw-Boris A, Zhou F, Kuo A \& Leder P 1996 Fibroblast growth factor receptor 3 is a negative regulator of bone growth. Cell $\mathbf{8 4}$ 911-921. (doi:10.1016/S0092-8674(00)81069-7)

Donate-Correa J, Muros-de-Fuentes M, Mora-Fernandez C \& NavarroGonzalez JF 2012 FGF23/Klotho axis: phosphorus, mineral metabolism and beyond. Cytokine \& Growth Factor Reviews 23 37-46. (doi:10.1016/j. cytogfr.2012.01.004)

Dooley J, Erickson M, Larochelle WJ, Gillard GO \& Farr AG 2007 FGFR2IIIb signaling regulates thymic epithelial differentiation. Developmental Dynamics 236 3459-3471. (doi:10.1002/dvdy.21364)

Du X, Xie Y, Xian CJ \& Chen L 2012 Role of FGFs/FGFRs in skeletal development and bone regeneration. Journal of Cellular Physiology 227 3731-3743. (doi:10.1002/jcp.24083)

El-Hoss J, Kolind M, Jackson MT, Deo N, Mikulec K, McDonald MM, Little CB, Little DG \& Schindeler A 2014 Modulation of endochondral ossification by MEK inhibitors PD0325901 and AZD6244 (Selumetinib). Bone 59 151-161. (doi:10.1016/j.bone.2013.11.013)

Elo T, Sipila P, Valve E, Kujala P, Toppari J, Poutanen M \& Harkonen P 2012 Fibroblast growth factor $8 \mathrm{~b}$ causes progressive stromal and epithelial changes in the epididymis and degeneration of the seminiferous epithelium in the testis of transgenic mice. Biology of Reproduction $\mathbf{8 6}$ 157, 151-112. (doi:10.1095/biolreprod.111.097352)

Eswarakumar VP, Monsonego-Ornan E, Pines M, Antonopoulou I, Morriss-Kay GM \& Lonai P 2002 The IIIc alternative of Fgfr 2 is a positive regulator of bone formation. Development 129 3783-3793.

Eswarakumar VP, Horowitz MC, Locklin R, Morriss-Kay GM \& Lonai P 2004 A gain-of-function mutation of $F g f r 2 c$ demonstrates the roles of this receptor variant in osteogenesis. PNAS 101 12555-12560. (doi:10.1073/ pnas.0405031101)

Eswarakumar VP, Lax I \& Schlessinger J 2005 Cellular signaling by fibroblast growth factor receptors. Cytokine \& Growth Factor Reviews 16 139-149. (doi:10.1016/j.cytogfr.2005.01.001)

Fallon JF, Lopez A, Ros MA, Savage MP, Olwin BB \& Simandl BK 1994 FGF-2: apical ectodermal ridge growth signal for chick limb development. Science 264 104-107. (doi:10.1126/science.7908145)

Fei Y \& Hurley MM 2012 Role of fibroblast growth factor 2 and Wnt signaling in anabolic effects of parathyroid hormone on bone formation. Journal of Cellular Physiology 227 3539-3545. (doi:10.1002/ jcp.24075)

Fei Y, Xiao L \& Hurley MM 2011 The impaired bone anabolic effect of PTH in the absence of endogenous FGF2 is partially due to reduced ATF4 expression. Biochemical and Biophysical Research Communications 412 160-164. (doi:10.1016/j.bbrc.2011.07.066)

Feteih R, Tassinari MS \& Lian JB 1990 Effect of sodium warfarin on vitamin K-dependent proteins and skeletal development in the rat fetus. Journal of Bone and Mineral Research 5 885-894. (doi:10.1002/ jbmr.5650050813)

Foldynova-Trantirkova S, Wilcox WR \& Krejci P 2012 Sixteen years and counting: the current understanding of fibroblast growth factor receptor 3 (FGFR3) signaling in skeletal dysplasias. Human Mutation 33 29-41. (doi:10.1002/humu.21636)

Fortin D, Rom E, Sun H, Yayon A \& Bansal R 2005 Distinct fibroblast growth factor (FGF)/FGF receptor signaling pairs initiate diverse cellular 
responses in the oligodendrocyte lineage. Journal of Neuroscience $\mathbf{2 5}$ 7470-7479. (doi:10.1523/JNEUROSCI.2120-05.2005)

de Frutos CA, Vega S, Manzanares M, Flores JM, Huertas H, Martinez-Frias ML \& Nieto MA 2007 Snail1 is a transcriptional effector of FGFR3 signaling during chondrogenesis and achondroplasias. Developmental Cell 13 872-883. (doi:10.1016/j.devcel.2007.09.016)

Fukumoto S \& Yamashita T 2007 FGF23 is a hormone-regulating phosphate metabolism - unique biological characteristics of FGF23. Bone $\mathbf{4 0}$ 1190-1195. (doi:10.1016/j.bone.2006.12.062)

Garcia S, Dirat B, Tognacci T, Rochet N, Mouska X, Bonnafous S, Patouraux S, Tran A, Gual P, Le Marchand-Brustel Y et al. 2013 Postnatal soluble FGFR3 therapy rescues achondroplasia symptoms and restores bone growth in mice. Science Translational Medicine 5 203ra124. (doi:10.1126/ scitranslmed.3006247)

Garofalo S, Kliger-Spatz M, Cooke JL, Wolstin O, Lunstrum GP, Moshkovitz SM, Horton WA \& Yayon A 1999 Skeletal dysplasia and defective chondrocyte differentiation by targeted overexpression of fibroblast growth factor 9 in transgenic mice. Journal of Bone and Mineral Research 14 1909-1915. (doi:10.1359/jbmr.1999.14.11.1909)

Gattineni J, Bates C, Twombley K, Dwarakanath V, Robinson ML, Goetz R, Mohammadi M \& Baum M 2009 FGF23 decreases renal NaPi-2a and $\mathrm{NaPi}-2 \mathrm{c}$ expression and induces hypophosphatemia in vivo predominantly via FGF receptor 1. American Journal of Physiology. Renal Physiology 297 F282-F291. (doi:10.1152/ajprenal.90742.2008)

Gattineni J, Twombley K, Goetz R, Mohammadi M \& Baum M 2011 Regulation of serum $1,25(\mathrm{OH})_{2}$ vitamin $\mathrm{D}_{3}$ levels by fibroblast growth factor 23 is mediated by FGF receptors 3 and 4. American Journal of Physiology. Renal Physiology 301 F371-F377. (doi:10.1152/ajprenal. 00740.2010)

Gattineni J, Alphonse P, Zhang Q, Mathews N, Bates CM \& Baum M 2014 Regulation of renal phosphate transport by FGF23 is mediated by FGFR1 and FGFR4. American Journal of Physiology. Renal Physiology $\mathbf{3 0 6}$ F351-F358. (doi:10.1152/ajprenal.00232.2013)

Gong SG 2012 The Fgfr $2_{\text {W290R }}$ mouse model of Crouzon syndrome. Child's Nervous System 28 1495-1503. (doi:10.1007/s00381-012-1792-y)

Gong SG 2014 Isoforms of receptors of fibroblast growth factors. Journal of Cellular Physiology [in press]. (doi:10.1002/jcp.24649)

Grillo L, Greco D, Pettinato R, Avola E, Potenza N, Castiglia L, Spalletta A, Amata S, Di Benedetto D, Luciano D et al. 2014 Increased FGF3 and FGF4 gene dosage is a risk factor for craniosynostosis. Gene $\mathbf{5 3 4}$ 435-439. (doi:10.1016/j.gene.2013.09.120)

Grimsrud CD, Romano PR, D'Souza M, Puzas JE, Schwarz EM, Reynolds PR, Roiser RN \& O'Keefe RJ 2001 BMP signaling stimulates chondrocyte maturation and the expression of Indian hedgehog. Journal of Orthopaedic Research 19 18-25. (doi:10.1016/S0736-0266(00)00017-6)

Gunhaga L, Marklund M, Sjodal M, Hsieh JC, Jessell TM \& Edlund T 2003 Specification of dorsal telencephalic character by sequential Wnt and FGF signaling. Nature Neuroscience 6 701-707. (doi:10.1038/nn1068)

Guo X, Mak KK, Taketo MM \& Yang Y 2009 The Wnt/ $\beta$-catenin pathway interacts differentially with PTHrP signaling to control chondrocyte hypertrophy and final maturation. PLOS ONE 4 e6067. (doi:10.1371/ journal.pone.0006067)

Hadari Y \& Schlessinger J 2009 FGFR3-targeted mAb therapy for bladder cancer and multiple myeloma. Journal of Clinical Investigation 119 1077-1079. (doi:10.1172/JCI38948)

Hafner C, Toll A, Fernandez-Casado A, Earl J, Marques M, Acquadro F, Mendez-Pertuz M, Urioste M, Malats N, Burns JE et al. 2010 Multiple oncogenic mutations and clonal relationship in spatially distinct benign human epidermal tumors. PNAS 107 20780-20785. (doi:10.1073/pnas.1008365107)

Hajihosseini MK, Wilson S, De Moerlooze L \& Dickson C 2001 A splicing switch and gain-of-function mutation in FgfR2-IIIc hemizygotes causes Apert/Pfeiffer-syndrome-like phenotypes. PNAS 98 3855-3860. (doi:10.1073/pnas.071586898)

Hajihosseini MK, Lalioti MD, Arthaud S, Burgar HR, Brown JM, Twigg SR, Wilkie AO \& Heath JK 2004 Skeletal development is regulated by fibroblast growth factor receptor 1 signalling dynamics. Development 131 325-335. (doi:10.1242/dev.00940)

Harada D, Yamanaka Y, Ueda K, Nishimura R, Morishima T, Seino Y \& Tanaka H 2007 Sustained phosphorylation of mutated FGFR3 is a crucial feature of genetic dwarfism and induces apoptosis in the ATDC5 chondrogenic cell line via PLC $\gamma$-activated STAT1. Bone 41 273-281. (doi:10.1016/j.bone.2006.11.030)

Harada M, Murakami H, Okawa A, Okimoto N, Hiraoka S, Nakahara T, Akasaka R, Shiraishi Y, Futatsugi N, Mizutani-Koseki Y et al. 2009 FGF9 monomer-dimer equilibrium regulates extracellular matrix affinity and tissue diffusion. Nature Genetics 41 289-298. (doi:10.1038/ng.316)

Hattori T, Muller C, Gebhard S, Bauer E, Pausch F, Schlund B, Bosl MR, Hess A, Surmann-Schmitt C, von der Mark H et al. 2010 SOX9 is a major negative regulator of cartilage vascularization, bone marrow formation and endochondral ossification. Development 137 901-911. (doi:10.1242/dev.045203)

He X, Xie F \& Ren ZR 2012 Rapid detection of G1138A and G1138C mutations of the FGFR3 gene in patients with achondroplasia using high-resolution melting analysis. Genetic Testing and Molecular Biomarkers 16 297-301. (doi:10.1089/gtmb.2011.0113)

Henderson JE, Naski MC, Aarts MM, Wang D, Cheng L, Goltzman D \& Ornitz DM 2000 Expression of FGFR3 with the G380R achondroplasia mutation inhibits proliferation and maturation of CFK2 chondrocytic cells. Journal of Bone and Mineral Research 15 155-165. (doi:10.1359/ jbmr.2000.15.1.155)

Huch K, Kleffner S, Stove J, Puhl W, Gunther KP \& Brenner RE 2003 PTHrP, PTHr, and FGFR3 are involved in the process of endochondral ossification in human osteophytes. Histochemistry and Cell Biology 119 281-287. (doi:10.1007/s00418-003-0519-2)

Hung IH, Yu K, Lavine KJ \& Ornitz DM 2007 FGF9 regulates early hypertrophic chondrocyte differentiation and skeletal vascularization in the developing stylopod. Developmental Biology 307 300-313. (doi:10.1016/j.ydbio.2007.04.048)

Hurley MM, Okada Y, Xiao L, Tanaka Y, Ito M, Okimoto N, Nakamura T, Rosen CJ, Doetschman T \& Coffin JD 2006 Impaired bone anabolic response to parathyroid hormone in Fgf2 - / - and Fgf2 + / - mice. Biochemical and Biophysical Research Communications 341 989-994. (doi:10.1016/j.bbrc.2006.01.044)

Iseki S, Wilkie AO, Heath JK, Ishimaru T, Eto K \& Morriss-Kay GM 1997 Fgfr 2 and osteopontin domains in the developing skull vault are mutually exclusive and can be altered by locally applied FGF2. Development 124 3375-3384.

Iseki S, Wilkie AO \& Morriss-Kay GM 1999 Fgfr1 and Fgfr2 have distinct differentiation- and proliferation-related roles in the developing mouse skull vault. Development 126 5611-5620.

Ishida K \& Haudenschild DR 2013 Interactions between FGF21 and BMP-2 in osteogenesis. Biochemical and Biophysical Research Communications 432 677-682. (doi:10.1016/j.bbrc.2013.02.019)

Itoh N \& Ornitz DM 2008 Functional evolutionary history of the mouse $F g f$ gene family. Developmental Dynamics 237 18-27. (doi:10.1002/dvdy. 21388)

Iwata T, Chen L, Li C, Ovchinnikov DA, Behringer RR, Francomano CA \& Deng CX 2000 A neonatal lethal mutation in FGFR3 uncouples proliferation and differentiation of growth plate chondrocytes in embryos. Human Molecular Genetics 9 1603-1613. (doi:10.1093/hmg/9.11.1603)

Iwata T, Li CL, Deng CX \& Francomano CA 2001 Highly activated Fgfr3 with the K644M mutation causes prolonged survival in severe dwarf mice. Human Molecular Genetics 10 1255-1264. (doi:10.1093/hmg/10.12.1255)

Jacob AL, Smith C, Partanen J \& Ornitz DM 2006 Fibroblast growth factor receptor 1 signaling in the osteo-chondrogenic cell lineage regulates sequential steps of osteoblast maturation. Developmental Biology $\mathbf{5 7}$ 315-328. (doi:10.1016/j.ydbio.2006.05.031)

Jarzabek K, Wolczynski S, Lesniewicz R, Plessis G \& Kottler ML 2012 Evidence that FGFR1 loss-of-function mutations may cause variable skeletal malformations in patients with Kallmann syndrome. Advances in Medical Sciences 57 314-321. (doi:10.2478/v10039-012-0036-4) 
Jin M, Yu Y, Qi H, Xie Y, Su N, Wang X, Tan Q, Luo F, Zhu Y, Wang Q et al. $2012 a$ A novel FGFR3-binding peptide inhibits FGFR3 signaling and reverses the lethal phenotype of mice mimicking human thanatophoric dysplasia. Human Molecular Genetics 21 5443-5455. (doi:10.1093/ hmg/dds390)

Jin M, Du X \& Chen L 2012b Cross-talk between FGF and other cytokine signalling pathways during endochondral bone development. Cell Biology International 36 691-696. (doi:10.1042/CBI20110352)

Jonquoy A, Mugniery E, Benoist-Lasselin C, Kaci N, Le Corre L, Barbault F, Girard AL, Le Merrer Y, Busca P, Schibler L et al. 2012 A novel tyrosine kinase inhibitor restores chondrocyte differentiation and promotes bone growth in a gain-of-function Fgfr3 mouse model. Human Molecular Genetics 21 841-851. (doi:10.1093/hmg/ddr514)

Jonsson KB, Zahradnik R, Larsson T, White KE, Sugimoto T, Imanishi Y, Yamamoto T, Hampson G, Koshiyama H, Ljunggren O et al. 2003 Fibroblast growth factor 23 in oncogenic osteomalacia and X-linked hypophosphatemia. New England Journal of Medicine 348 1656-1663. (doi:10.1056/NEJMoa020881)

Kamath AV, Lu D, Gupta P, Jin D, Xin Y, Brady A, Stephan JP, Li H, Tien J, Qing J et al. 2012 Preclinical pharmacokinetics of MFGR1877A, a human monoclonal antibody to FGFR3, and prediction of its efficacious clinical dose for the treatment of $\mathrm{t}(4 ; 14)$-positive multiple myeloma. Cancer Chemotherapy and Pharmacology 69 1071-1078. (doi:10.1007/s00280-011-1807-5)

Karsenty G \& Wagner EF 2002 Reaching a genetic and molecular understanding of skeletal development. Developmental Cell 2 389-406. (doi:10.1016/S1534-5807(02)00157-0)

Karsenty G, Kronenberg HM \& Settembre C 2009 Genetic control of bone formation. Annual Review of Cell and Developmental Biology 25 629-648. (doi:10.1146/annurev.cellbio.042308.113308)

Kawai M, Kinoshita S, Kimoto A, Hasegawa Y, Miyagawa K, Yamazaki M, Ohata Y, Ozono K \& Michigami T 2013 FGF23 suppresses chondrocyte proliferation in the presence of soluble $\alpha$-Klotho both in vitro and in vivo. Journal of Biological Chemistry 288 2414-2427. (doi:10.1074/jbc. M112.410043)

Keats JJ, Reiman T, Maxwell CA, Taylor BJ, Larratt LM, Mant MJ, Belch AR \& Pilarski LM 2003 In multiple myeloma, $t(4 ; 14)(\mathrm{p} 16 ; \mathrm{q} 32)$ is an adverse prognostic factor irrespective of FGFR3 expression. Blood $\mathbf{1 0 1}$ 1520-1529. (doi:10.1182/blood-2002-06-1675)

Kerkhofs J, Roberts SJ, Luyten FP, Van Oosterwyck H \& Geris L 2012 Relating the chondrocyte gene network to growth plate morphology: from genes to phenotype. PLoS ONE 7 e34729. (doi:10.1371/journal. pone.0034729)

King N, Odom TW, Sampson HW \& Yersin AG 1991 The effect of in ovo boron supplementation on bone mineralization of the vitamin D-deficient chicken embryo. Biological Trace Element Research 31 223-233. (doi:10.1007/BF02990193)

Kobayashi T, Chung UI, Schipani E, Starbuck M, Karsenty G, Katagiri T, Goad DL, Lanske B \& Kronenberg HM 2002 PTHrP and Indian hedgehog control differentiation of growth plate chondrocytes at multiple steps. Development 129 2977-2986.

Krejci P 2014 The paradox of FGFR3 signaling in skeletal dysplasia: why chondrocytes growth arrest while other cells over proliferate. Mutation Research. Reviews in Mutation Research 759 40-48. (doi:10.1016/j.mrrev. 2013.11.001)

Krejci P, Bryja V, Pachernik J, Hampl A, Pogue R, Mekikian P \& Wilcox WR 2004 FGF2 inhibits proliferation and alters the cartilage-like phenotype of RCS cells. Experimental Cell Research 297 152-164. (doi:10.1016/j. yexcr.2004.03.011)

Krejci P, Masri B, Fontaine V, Mekikian PB, Weis M, Prats H \& Wilcox WR 2005 Interaction of fibroblast growth factor and C-natriuretic peptide signaling in regulation of chondrocyte proliferation and extracellular matrix homeostasis. Journal of Cell Science 118 5089-5100. (doi:10. $1242 /$ jcs.02618)

Krejci P, Krakow D, Mekikian PB \& Wilcox WR 2007 Fibroblast growth factors 1, 2, 17, and 19 are the predominant FGF ligands expressed in human fetal growth plate cartilage. Pediatric Research 61 267-272. (doi:10.1203/pdr.0b013e318030d157)

Krejci P, Prochazkova J, Smutny J, Chlebova K, Lin P, Aklian A, Bryja V, Kozubik A \& Wilcox WR 2010 FGFR3 signaling induces a reversible senescence phenotype in chondrocytes similar to oncogene-induced premature senescence. Bone 47 102-110. (doi:10.1016/j.bone.2010.03.021)

Krejci P, Aklian A, Kaucka M, Sevcikova E, Prochazkova J, Masek JK, Mikolka P, Pospisilova T, Spoustova T, Weis M et al. 2012 Receptor tyrosine kinases activate canonical $\mathrm{WNT} / \beta$-catenin signaling via MAP kinase/LRP6 pathway and direct $\beta$-catenin phosphorylation. PLOS ONE 7 e35826. (doi:10.1371/journal.pone.0035826)

Kyono A, Avishai N, Ouyang Z, Landreth GE \& Murakami S 2012 FGF and ERK signaling coordinately regulate mineralization-related genes and play essential roles in osteocyte differentiation. Journal of Bone and Mineral Metabolism 30 19-30. (doi:10.1007/s00774-011-0288-2)

Lango Allen H, Estrada K, Lettre G, Berndt SI, Weedon MN, Rivadeneira F, Willer CJ, Jackson AU, Vedantam S, Raychaudhuri S et al. 2010 Hundreds of variants clustered in genomic loci and biological pathways affect human height. Nature 467 832-838. (doi:10.1038/nature09410)

Larbuisson A, Dalcq J, Martial JA \& Muller M 2013 Fgf receptors Fgfr1a and Fgfr2 control the function of pharyngeal endoderm in late cranial cartilage development. Differentiation 86 192-206. (doi:10.1016/j.diff. 2013.07.006)

Larsson T, Marsell R, Schipani E, Ohlsson C, Ljunggren O, Tenenhouse HS, Juppner $\mathrm{H} \&$ Jonsson KB 2004 Transgenic mice expressing fibroblast growth factor 23 under the control of the $\alpha 1$ (I) collagen promoter exhibit growth retardation, osteomalacia, and disturbed phosphate homeostasis. Endocrinology 145 3087-3094. (doi:10.1210/en.2003-1768)

Lazarus JE, Hegde A, Andrade AC, Nilsson O \& Baron J 2007 Fibroblast growth factor expression in the postnatal growth plate. Bone $\mathbf{4 0}$ 577-586. (doi:10.1016/j.bone.2006.10.013)

Lee S, Chen TT, Barber CL, Jordan MC, Murdock J, Desai S, Ferrara N, Nagy A, Roos KP \& Iruela-Arispe ML 2007 Autocrine VEGF signaling is required for vascular homeostasis. Cell 130 691-703. (doi:10.1016/j. cell.2007.06.054)

Lemonnier J, Hay E, Delannoy P, Fromigue O, Lomri A, Modrowski D \& Marie PJ 2001 Increased osteoblast apoptosis in Apert craniosynostosis: role of protein kinase C and interleukin-1. American Journal of Pathology 158 1833-1842. (doi:10.1016/S0002-9440(10)64139-9)

Leung VY, Gao B, Leung KK, Melhado IG, Wynn SL, Au TY, Dung NW, Lau JY, Mak AC, Chan D et al. 2011 SOX9 governs differentiation stage-specific gene expression in growth plate chondrocytes via direct concomitant transactivation and repression. PLoS Genetics 7 e1002356. (doi:10.1371/journal.pgen.1002356)

L'Hote CG \& Knowles MA 2005 Cell responses to FGFR3 signalling: growth, differentiation and apoptosis. Experimental Cell Research 304 417-431. (doi:10.1016/j.yexcr.2004.11.012)

Li C, Chen L, Iwata T, Kitagawa M, Fu XY \& Deng CX 1999 A Lys644Glu substitution in fibroblast growth factor receptor 3 (FGFR3) causes dwarfism in mice by activation of STATs and ink 4 cell cycle inhibitors. Human Molecular Genetics 8 35-44. (doi:10.1093/hmg/8.1.35)

Li M, Seki Y, Freitas PH, Nagata M, Kojima T, Sultana S, Ubaidus S, Maeda T, Shimomura J. Henderson JE et al. 2010 FGFR3 down-regulates $\mathrm{PTH} / \mathrm{PTHrP}$ receptor gene expression by mediating JAK/STAT signaling in chondrocytic cell line. Journal of Electron Microscopy 59 227-236. (doi:10.1093/jmicro/dfq002)

Li H, Martin A, David V \& Quarles LD 2011a Compound deletion of Fgfr3 and Fgfr4 partially rescues the Hyp mouse phenotype. American Journal of Physiology. Endocrinology and Metabolism 300 E508-E517. (doi:10.1152/ajpendo.00499.2010)

Li H, Haurigot V, Doyon Y, Li T, Wong SY, Bhagwat AS, Malani N, Anguela $\mathrm{XM}$, Sharma R, Ivanciu L et al. $2011 \mathrm{~b}$ In vivo genome editing restores haemostasis in a mouse model of haemophilia. Nature 475 217-221. (doi:10.1038/nature10177)

Lin RZ \& Melero-Martin JM 2012 Fibroblast growth factor-2 facilitates rapid anastomosis formation between bioengineered human vascular 
networks and living vasculature. Methods 56 440-451. (doi:10.1016/j. ymeth.2012.01.006)

Lin JM, Callon KE, Lin JS, Watson M, Empson V, Tong PC, Grey A, Naot D, Green CR, Reid IR et al. 2009 Actions of fibroblast growth factor-8 in bone cells in vitro. American Journal of Physiology. Endocrinology and Metabolism 297 E142-E150. (doi:10.1152/ajpendo.90743.2008)

Liu Z, Xu J, Colvin JS \& Ornitz DM 2002 Coordination of chondrogenesis and osteogenesis by fibroblast growth factor 18. Genes and Development 16 859-869. (doi:10.1101/gad.965602)

Liu S, Zhou J, Tang W, Jiang X, Rowe DW \& Quarles LD 2006 Pathogenic role of Fgf23 in Hyp mice. American Journal of Physiology. Endocrinology and Metabolism 291 E38-E49. (doi:10.1152/ajpendo.00008.2006)

Liu Z, Lavine KJ, Hung IH \& Ornitz DM 2007 FGF18 is required for early chondrocyte proliferation, hypertrophy and vascular invasion of the growth plate. Developmental Biology 302 80-91. (doi:10.1016/j.ydbio. 2006.08.071)

Lokody I 2014 Genetic therapies: correcting genetic defects with CRISPRCas9. Nature Reviews. Genetics 15 63. (doi:10.1038/nrg3656)

Lomri A, Lemonnier J, Hott M, de Parseval N, Lajeunie E, Munnich A, Renier D \& Marie PJ 1998 Increased calvaria cell differentiation and bone matrix formation induced by fibroblast growth factor receptor 2 mutations in Apert syndrome. Journal of Clinical Investigation 101 1310-1317. (doi:10.1172/JCI119886)

Lomri A, Lemonnier J, Delannoy P \& Marie PJ 2001 Increased expression of protein kinase $\mathrm{C} \alpha$, interleukin- $1 \alpha$, and RhoA guanosine $5^{\prime}$-triphosphatase in osteoblasts expressing the Ser252Trp fibroblast growth factor 2 receptor Apert mutation: identification by analysis of complementary DNA microarray. Journal of Bone and Mineral Research 16 705-712. (doi:10.1359/jbmr.2001.16.4.705)

Long F \& Ornitz DM 2013 Development of the endochondral skeleton. Cold Spring Harbor Perspectives in Biology 5 a008334. (doi:10.1101/ cshperspect.a008334)

Lorget F, Kaci N, Peng J, Benoist-Lasselin C, Mugniery E, Oppeneer T, Wendt DJ, Bell SM, Bullens S, Bunting S et al. 2012 Evaluation of the therapeutic potential of a CNP analog in a Fgfr3 mouse model recapitulating achondroplasia. American Journal of Human Genetics 91 1108-1114. (doi:10.1016/j.ajhg.2012.10.014)

Lu Y \& Feng JQ 2011 FGF23 in skeletal modeling and remodeling. Current Osteoporosis Reports 9 103-108. (doi:10.1007/s11914-011-0053-4)

Lu X, Su N, Yang J, Huang W, Li C, Zhao L, He Q, Du X, Shen Y, Chen B et al. 2009 Fibroblast growth factor receptor 1 regulates the differentiation and activation of osteoclasts through Erk1/2 pathway. Biochemical and Biophysical Research Communications 390 494-499. (doi:10.1016/j.bbrc. 2009.09.123)

Lui JC, Nilsson O, Chan Y, Palmer CD, Andrade AC, Hirschhorn JN \& Baron J 2012 Synthesizing genome-wide association studies and expression microarray reveals novel genes that act in the human growth plate to modulate height. Human Molecular Genetics 21 5193-5201. (doi:10. 1093/hmg/dds347)

Ma N, Liao B, Zhang H, Wang L, Shan Y, Xue Y, Huang K, Chen S, Zhou X, Chen $Y$ et al. 2013 Transcription activator-like effector nuclease (TALEN)-mediated gene correction in integration-free $\beta$-thalassemia induced pluripotent stem cells. Journal of Biological Chemistry $\mathbf{2 8 8}$ 34671-34679. (doi:10.1074/jbc.M113.496174)

Maes C, Kobayashi T, Selig MK, Torrekens S, Roth SI, Mackem S, Carmeliet G \& Kronenberg HM 2010 Osteoblast precursors, but not mature osteoblasts, move into developing and fractured bones along with invading blood vessels. Developmental Cell 19 329-344. (doi:10.1016/j. devcel.2010.07.010)

Mangion J, Rahman N, Edkins S, Barfoot R, Nguyen T, Sigurdsson A, Townend JV, Fitzpatrick DR, Flanagan AM \& Stratton MR 1999 The gene for cherubism maps to chromosome $4 \mathrm{p} 16.3$. American Journal of Human Genetics 65 151-157. (doi:10.1086/302454)

Mansukhani A, Bellosta P, Sahni M \& Basilico C 2000 Signaling by fibroblast growth factors (FGF) and fibroblast growth factor receptor 2 (FGFR2)-activating mutations blocks mineralization and induces apoptosis in osteoblasts. Journal of Cell Biology 149 1297-1308. (doi:10.1083/jcb.149.6.1297)

Mansukhani A, Ambrosetti D, Holmes G, Cornivelli L \& Basilico C 2005 Sox2 induction by FGF and FGFR2 activating mutations inhibits Wnt signaling and osteoblast differentiation. Journal of Cell Biology 168 1065-1076. (doi:10.1083/jcb.200409182)

Mariani FV, Ahn CP \& Martin GR 2008 Genetic evidence that FGFs have an instructive role in limb proximal-distal patterning. Nature $\mathbf{4 5 3}$ 401-405. (doi:10.1038/nature06876)

Marie PJ, Coffin JD \& Hurley MM 2005 FGF and FGFR signaling in chondrodysplasias and craniosynostosis. Journal of Cellular Biochemistry 96 888-896. (doi:10.1002/jcb.20582)

Marie PJ, Miraoui H \& Severe N 2012 FGF/FGFR signaling in bone formation: progress and perspectives. Growth Factors 30 117-123. (doi:10.3109/08977194.2012.656761)

Martin GR 1998 The roles of FGFs in the early development of vertebrate limbs. Genes and Development 12 1571-1586. (doi:10.1101/gad.12.11. 1571)

Martinez-Frias ML, de Frutos CA, Bermejo E \& Nieto MA 2010 Review of the recently defined molecular mechanisms underlying thanatophoric dysplasia and their potential therapeutic implications for achondroplasia. American Journal of Medical Genetics. Part A 152A 245-255. (doi:10.1002/ajmg.a.33188)

Matsushita T, Wilcox WR, Chan YY, Kawanami A, Bukulmez H, Balmes G, Krejci P, Mekikian PB, Otani K, Yamaura I et al. 2009 FGFR3 promotes synchondrosis closure and fusion of ossification centers through the MAPK pathway. Human Molecular Genetics 18 227-240. (doi:10.1093/ hmg/ddn339)

Matsushita M, Kitoh H, Ohkawara B, Mishima K, Kaneko H, Ito M, Masuda A, Ishiguro N \& Ohno K 2013 Meclozine facilitates proliferation and differentiation of chondrocytes by attenuating abnormally activated FGFR3 signaling in achondroplasia. PLoS One 8 e81569. (doi:10.1371/ journal.pone.0081569)

Mayahara H, Ito T, Nagai H, Miyajima H, Tsukuda R, Taketomi S, Mizoguchi J \& Kato K 1993 In vivo stimulation of endosteal bone formation by basic fibroblast growth factor in rats. Growth Factors 9 73-80. (doi:10.3109/08977199308991583)

Mendelsohn AR \& Larrick JW 2012 Fibroblast growth factor-21 is a promising dietary restriction mimetic. Rejuvenation Research $\mathbf{1 5}$ 624-628. (doi:10.1089/rej.2012.1392)

Merrill AE, Sarukhanov A, Krejci P, Idoni B, Camacho N, Estrada KD, Lyons KM, Deixler H, Robinson H, Chitayat D et al. 2012 Bent bone dysplasiaFGFR2 type, a distinct skeletal disorder, has deficient canonical FGF signaling. American Journal of Human Genetics 90 550-557. (doi:10.1016/j.ajhg.2012.02.005)

Meyers GA, Orlow SJ, Munro IR, Przylepa KA \& Jabs EW 1995 Fibroblast growth factor receptor 3 (FGFR3) transmembrane mutation in Crouzon syndrome with acanthosis nigricans. Nature Genetics $11462-464$. (doi:10.1038/ng1295-462)

Michigami T 2013 Regulatory mechanisms for the development of growth plate cartilage. Cellular and Molecular Life Sciences 70 4213-4221. (doi:10.1007/s00018-013-1346-9)

Milunsky JM, Zhao G, Maher TA, Colby R \& Everman DB 2006 LADD syndrome is caused by FGF10 mutations. Clinical Genetics 69 349-354. (doi:10.1111/j.1399-0004.2006.00597.x)

Minina E, Wenzel HM, Kreschel C, Karp S, Gaffield W, McMahon AP \& Vortkamp A 2001 BMP and Ihh/PTHrP signaling interact to coordinate chondrocyte proliferation and differentiation. Development 128 4523-4534.

Minina E, Kreschel C, Naski MC, Ornitz DM \& Vortkamp A 2002 Interaction of FGF, Ihh/Pthlh, and BMP signaling integrates chondrocyte proliferation and hypertrophic differentiation. Developmental Cell 3 439-449. (doi:10.1016/S1534-5807(02)00261-7)

Minina E, Schneider S, Rosowski M, Lauster R \& Vortkamp A 2005 Expression of Fgf and Tgfbeta signaling related genes during embryonic 
endochondral ossification. Gene Expression Patterns 6 102-109. (doi:10. 1016/j.modgep.2005.04.012)

Montero A, Okada Y, Tomita M, Ito M, Tsurukami H, Nakamura T, Doetschman T, Coffin JD \& Hurley MM 2000 Disruption of the fibroblast growth factor-2 gene results in decreased bone mass and bone formation. Journal of Clinical Investigation 105 1085-1093. (doi:10. 1172/JCI8641)

Moon AM \& Capecchi MR 2000 Fgf8 is required for outgrowth and patterning of the limbs. Nature Genetics 26 455-459. (doi:10.1038/ 82601)

Moon AM, Boulet AM \& Capecchi MR 2000 Normal limb development in conditional mutants of Fgf4. Development 127 989-996.

Morita J, Nakamura M, Kobayashi Y, Deng CX, Funato N \& Moriyama K 2014 Soluble form of FGFR2 with S252W partially prevents craniosynostosis of the Apert mouse model. Developmental Dynamics $\mathbf{2 4 3}$ 560-567. (doi:10.1002/dvdy.24099)

Muenke M, Schell U, Hehr A, Robin NH, Losken HW, Schinzel A, Pulleyn LJ, Rutland P, Reardon W, Malcolm S et al. 1994 A common mutation in the fibroblast growth factor receptor 1 gene in Pfeiffer syndrome. Nature Genetics 8 269-274. (doi:10.1038/ng1194-269)

Muenke M, Gripp KW, McDonald-McGinn DM, Gaudenz K, Whitaker LA, Bartlett SP, Markowitz RI, Robin NH, Nwokoro N, Mulvihill JJ et al. 1997 A unique point mutation in the fibroblast growth factor receptor 3 gene (FGFR3) defines a new craniosynostosis syndrome. American Journal of Human Genetics 60 555-564.

Mugniery E, Dacquin R, Marty C, Benoist-Lasselin C, de Vernejoul MC, Jurdic P, Munnich A, Geoffroy V \& Legeai-Mallet L 2012 An activating Fgfr3 mutation affects trabecular bone formation via a paracrine mechanism during growth. Human Molecular Genetics 21 2503-2513. (doi:10.1093/hmg/dds065)

Murakami H, Okawa A, Yoshida H, Nishikawa S, Moriya H \& Koseki H 2002 Elbow knee synostosis (Eks): a new mutation on mouse chromosome 14. Mammalian Genome 13 341-344. (doi:10.1007/s00335-001-2143-6)

Murakami S, Balmes G, McKinney S, Zhang Z, Givol D \& de Crombrugghe B 2004 Constitutive activation of MEK1 in chondrocytes causes Stat1independent achondroplasia-like dwarfism and rescues the Fgfr3deficient mouse phenotype. Genes and Development 18 290-305. (doi:10.1101/gad.1179104)

Nakamura T, Hanada K, Tamura M, Shibanushi T, Nigi H, Tagawa M, Fukumoto S \& Matsumoto T 1995 Stimulation of endosteal bone formation by systemic injections of recombinant basic fibroblast growth factor in rats. Endocrinology 136 1276-1284. (doi:10.1210/endo. 136.3.7867582)

Naski MC, Colvin JS, Coffin JD \& Ornitz DM 1998 Repression of hedgehog signaling and BMP4 expression in growth plate cartilage by fibroblast growth factor receptor 3. Development 125 4977-4988.

Nowroozi N, Raffioni S, Wang T, Apostol BL, Bradshaw RA \& Thompson LM 2005 Sustained ERK1/2 but not STAT1 or 3 activation is required for thanatophoric dysplasia phenotypes in PC12 cells. Human Molecular Genetics 14 1529-1538. (doi:10.1093/hmg/ddi161)

Ochiai H, Miyamoto T, Kanai A, Hosoba K, Sakuma T, Kudo Y, Asami K, Ogawa A, Watanabe A, Kajii T et al. 2014 TALEN-mediated single-basepair editing identification of an intergenic mutation upstream of BUB1B as causative of PCS (MVA) syndrome. PNAS 111 1461-1466. (doi:10.1073/pnas.1317008111)

Ogata H, Wada Y \& Akizawa T 2008 Role of kidney in calcium homeostasis and premature aging. Clinical Calcium 18 942-946.

Ohbayashi N, Shibayama M, Kurotaki Y, Imanishi M, Fujimori T, Itoh N \& Takada S 2002 FGF18 is required for normal cell proliferation and differentiation during osteogenesis and chondrogenesis. Genes and Development 16 870-879. (doi:10.1101/gad.965702)

Ohuchi H, Nakagawa T, Yamamoto A, Araga A, Ohata T, Ishimaru Y, Yoshioka H, Kuwana T, Nohno T, Yamasaki M et al. 1997 The mesenchymal factor, FGF10, initiates and maintains the outgrowth of the chick limb bud through interaction with FGF8, an apical ectodermal factor. Development 124 2235-2244.
Okada Y, Montero A, Zhang X, Sobue T, Lorenzo J, Doetschman T, Coffin JD \& Hurley MM 2003 Impaired osteoclast formation in bone marrow cultures of Fgf2 null mice in response to parathyroid hormone. Journal of Biological Chemistry 278 21258-21266. (doi:10.1074/jbc. M302113200)

Olsen BR, Reginato AM \& Wang W 2000 Bone development. Annual Review of Cell and Developmental Biology 16 191-220. (doi:10.1146/annurev. cellbio.16.1.191)

Omoteyama K \& Takagi M 2009 FGF8 regulates myogenesis and induces Runx2 expression and osteoblast differentiation in cultured cells. Journal of Cellular Biochemistry 106 546-552. (doi:10.1002/jcb.22012)

Ornitz DM 2005 FGF signaling in the developing endochondral skeleton. Cytokine \& Growth Factor Reviews 16 205-213. (doi:10.1016/j.cytogfr. 2005.02.003)

Ornitz DM \& Itoh N 2001 Fibroblast growth factors. Genome Biology 2. REVIEWS3005. (doi:10.1186/gb-2001-2-3-reviews3005)

Ornitz DM \& Marie PJ 2002 FGF signaling pathways in endochondral and intramembranous bone development and human genetic disease. Genes and Development 16 1446-1465. (doi:10.1101/gad.990702)

Orr-Urtreger A, Bedford MT, Burakova T, Arman E, Zimmer Y, Yayon A, Givol D \& Lonai P 1993 Developmental localization of the splicing alternatives of fibroblast growth factor receptor-2 (FGFR2). Developmental Biology 158 475-486. (doi:10.1006/dbio.1993.1205)

Ortega N, Behonick DJ \& Werb Z 2004 Matrix remodeling during endochondral ossification. Trends in Cell Biology 14 86-93. (doi:10.1016/j.tcb.2003.12.003)

Ozasa A, Komatsu Y, Yasoda A, Miura M, Sakuma Y, Nakatsuru Y, Arai H, Itoh $\mathrm{N} \&$ Nakao K 2005 Complementary antagonistic actions between C-type natriuretic peptide and the MAPK pathway through FGFR-3 in ATDC5 cells. Bone 36 1056-1064. (doi:10.1016/j.bone.2005.03.006)

Pannier S, Couloigner V, Messaddeq N, Elmaleh-Berges M, Munnich A, Romand R \& Legeai-Mallet L 2009 Activating Fgfr3 Y367C mutation causes hearing loss and inner ear defect in a mouse model of chondrodysplasia. Biochimica et Biophysica Acta 1792 140-147. (doi:10.1016/j.bbadis.2008.11.010)

Parafioriti A, del Bianco S, Barisani D, Armiraglio E, Peretti G \& Albisetti W 2009 Increased p21 expression in chondrocytes of achondroplasic children independently from the presence of the G380R FGFR3 mutation. Journal of Orthopaedic Science 14 623-630. (doi:10.1007/ s00776-009-1355-6)

Park MS, Rieger-Fackeldey E, Schanbacher BL, Cook AC, Bauer JA, Rogers LK, Hansen TN, Welty SE \& Smith CV 2007 Altered expressions of fibroblast growth factor receptors and alveolarization in neonatal mice exposed to 85\% oxygen. Pediatric Research 62 652-657. (doi:10.1203/ PDR.0b013e318159af61)

Park J, Park OJ, Yoon WJ, Kim HJ, Choi KY, Cho TJ \& Ryoo HM 2012 Functional characterization of a novel FGFR2 mutation, E731K, in craniosynostosis. Journal of Cellular Biochemistry 113 457-464. (doi:10.1002/jcb.23368)

Partanen J, Makela TP, Eerola E, Korhonen J, Hirvonen H, Claesson-Welsh L \& Alitalo K 1991 FGFR-4, a novel acidic fibroblast growth factor receptor with a distinct expression pattern. EMBO Journal 10 1347-1354.

Perry RW, Rowland GN \& Britton WM 1991 Pathology of experimental vitamin D deficiency in turkeys and the effects of various vitamin D supplements. Avian Diseases 35 542-553. (doi:10.2307/1591218)

Peters KG, Werner S, Chen G \& Williams LT 1992 Two FGF receptor genes are differentially expressed in epithelial and mesenchymal tissues during limb formation and organogenesis in the mouse. Development $114233-243$

Peters K, Ornitz D, Werner S \& Williams L 1993 Unique expression pattern of the FGF receptor 3 gene during mouse organogenesis. Developmental Biology 155 423-430. (doi:10.1006/dbio.1993.1040)

Powers CJ, McLeskey SW \& Wellstein A 2000 Fibroblast growth factors, their receptors and signaling. Endocrine-Related Cancer 7 165-197. (doi:10.1677/erc.0.0070165) 
Priore R, Dailey L \& Basilico C 2006 Downregulation of Akt activity contributes to the growth arrest induced by FGF in chondrocytes. Journal of Cellular Physiology 207 800-808. (doi:10.1002/jcp.20620)

Provot S \& Schipani E 2005 Molecular mechanisms of endochondral bone development. Biochemical and Biophysical Research Communications 328 658-665. (doi:10.1016/j.bbrc.2004.11.068)

Qi H, Jin M, Duan Y, Du X, Zhang Y, Ren F, Wang Y, Tian Q, Wang X, Wang $\mathrm{Q}$ et al. 2014 FGFR3 induces degradation of BMP type I receptor to regulate skeletal development. Biochimica et Biophysica Acta 1843 1237-1247. (doi:10.1016/j.bbamcr.2014.03.011)

Qing J, Du X, Chen Y, Chan P, Li H, Wu P, Marsters S, Stawicki S, Tien J, Totpal K et al. 2009 Antibody-based targeting of FGFR3 in bladder carcinoma and $\mathrm{t}(4 ; 14)$-positive multiple myeloma in mice. Journal of Clinical Investigation 119 1216-1229. (doi:10.1172/JCI38017)

Raimann A, Ertl DA, Helmreich M, Sagmeister S, Egerbacher M \& Haeusler G 2013 Fibroblast growth factor 23 and Klotho are present in the growth plate. Connective Tissue Research 54 108-117. (doi:10.3109/ 03008207.2012.753879)

Raucci A, Laplantine E, Mansukhani A \& Basilico C 2004 Activation of the ERK1/2 and p38 mitogen-activated protein kinase pathways mediates fibroblast growth factor-induced growth arrest of chondrocytes. Journal of Biological Chemistry 279 1747-1756. (doi:10.1074/jbc. M310384200)

Retting KN, Song B, Yoon BS \& Lyons KM 2009 BMP canonical Smad signaling through Smad1 and Smad5 is required for endochondral bone formation. Development 136 1093-1104. (doi:10.1242/dev.029926)

van Rhijn BW, van Tilborg AA, Lurkin I, Bonaventure J, de Vries A, Thiery JP, van der Kwast TH, Zwarthoff EC \& Radvanyi F 2002 Novel fibroblast growth factor receptor 3 (FGFR3) mutations in bladder cancer previously identified in non-lethal skeletal disorders. European Journal of Human Genetics 10 819-824. (doi:10.1038/sj.ejhg.5200883)

Rice DP, Aberg T, Chan Y, Tang Z, Kettunen PJ, Pakarinen L, Maxson RE \& Thesleff I 2000 Integration of FGF and TWIST in calvarial bone and suture development. Development 127 1845-1855.

Rice DP, Rice R \& Thesleff I 2003 Fgfr mRNA isoforms in craniofacial bone development. Bone 33 14-27. (doi:10.1016/S8756-3282(03)00163-7)

Riley BM, Mansilla MA, Ma J, Daack-Hirsch S, Maher BS, Raffensperger LM, Russo ET, Vieira AR, Dode C, Mohammadi M et al. 2007 Impaired FGF signaling contributes to cleft lip and palate. PNAS 104 4512-4517. (doi:10.1073/pnas.0607956104)

Rohmann E, Brunner HG, Kayserili H, Uyguner O, Nurnberg G, Lew ED, Dobbie A, Eswarakumar VP, Uzumcu A, Ulubil-Emeroglu M et al. 2006 Mutations in different components of FGF signaling in LADD syndrome. Nature Genetics 38 414-417. (doi:10.1038/ng1757)

Sabbieti MG, Agas D, Xiao L, Marchetti L, Coffin JD, Doetschman T \& Hurley MM 2009 Endogenous FGF-2 is critically important in PTH anabolic effects on bone. Journal of Cellular Physiology 219 143-151. (doi:10.1002/jcp.21661)

Sabbieti MG, Agas D, Marchetti L, Santoni G, Amantini C, Xiao L, Menghi $\mathrm{G} \&$ Hurley MM 2010 Signaling pathways implicated in $\mathrm{PGF}_{2 \alpha}$ effects on Fgf2 + / + and Fgf2-/ - osteoblasts. Journal of Cellular Physiology 224 465-474. (doi:10.1002/jcp.22143)

Sahni M, Ambrosetti DC, Mansukhani A, Gertner R, Levy D \& Basilico C 1999 FGF signaling inhibits chondrocyte proliferation and regulates bone development through the STAT-1 pathway. Genes and Development 13 1361-1366. (doi:10.1101/gad.13.11.1361)

Schwartz Z, Swain LD, Kelly DW, Brooks B \& Boyan BD 1992 Regulation of prostaglandin $\mathrm{E}_{2}$ production by vitamin $\mathrm{D}$ metabolites in growth zone and resting zone chondrocyte cultures is dependent on cell maturation. Bone 13 395-401. (doi:10.1016/8756-3282(92)90456-7)

Sebastian A, Matsushita T, Kawanami A, Mackem S, Landreth GE \& Murakami S 2011 Genetic inactivation of ERK1 and ERK2 in chondrocytes promotes bone growth and enlarges the spinal canal. Journal of Orthopaedic Research 29 375-379. (doi:10.1002/jor.21262)

Segev O, Chumakov I, Nevo Z, Givol D, Madar-Shapiro L, Sheinin Y, Weinreb M \& Yayon A 2000 Restrained chondrocyte proliferation and maturation with abnormal growth plate vascularization and ossification in human FGFR-3 $3^{\mathrm{G} 380 \mathrm{R}}$ transgenic mice. Human Molecular Genetics 9 249-258. (doi:10.1093/hmg/9.2.249)

Shalhoub V, Ward SC, Sun B, Stevens J, Renshaw L, Hawkins N \& Richards WG 2011 Fibroblast growth factor 23 (FGF23) and alpha-klotho stimulate osteoblastic MC3T3.E1 cell proliferation and inhibit mineralization. Calcified Tissue International 89 140-150. (doi:10.1007/ s00223-011-9501-5)

Shams I, Rohmann E, Eswarakumar VP, Lew ED, Yuzawa S, Wollnik B, Schlessinger J \& Lax I 2007 Lacrimo-auriculo-dento-digital syndrome is caused by reduced activity of the fibroblast growth factor 10 (FGF10)FGF receptor 2 signaling pathway. Molecular and Cellular Biology 27 6903-6912. (doi:10.1128/MCB.00544-07)

Shapiro IM, Adams CS, Freeman T \& Srinivas V 2005 Fate of the hypertrophic chondrocyte: microenvironmental perspectives on apoptosis and survival in the epiphyseal growth plate. Birth Defects Research. Part C, Embryo Today: Reviews 75 330-339. (doi:10.1002/bdrc. 20057)

Sharma VP, Wall SA, Lord H, Lester T \& Wilkie AO 2012 Atypical Crouzon syndrome with a novel Cys62Arg mutation in FGFR2 presenting with sagittal synostosis. Cleft Palate-Craniofacial Journal 49 373-377. (doi:10.1597/11-185)

Shimada T \& Fukumoto S 2012 FGF23 as a novel therapeutic target. Advances in Experimental Medicine and Biology 728 158-170. (doi:10. 1007/978-1-4614-0887-1_10)

Shimada T, Mizutani S, Muto T, Yoneya T, Hino R, Takeda S, Takeuchi Y, Fujita T, Fukumoto S \& Yamashita T 2001 Cloning and characterization of FGF23 as a causative factor of tumor-induced osteomalacia. PNAS 98 6500-6505. (doi:10.1073/pnas.101545198)

Shimada T, Urakawa I, Yamazaki Y, Hasegawa H, Hino R, Yoneya T, Takeuchi Y, Fujita T, Fukumoto S \& Yamashita T 2004 FGF-23 transgenic mice demonstrate hypophosphatemic rickets with reduced expression of sodium phosphate cotransporter type IIa. Biochemical and Biophysical Research Communications 314 409-414. (doi:10.1016/j.bbrc. 2003.12.102

Shinde DN, Elmer DP, Calabrese P, Boulanger J, Arnheim N \& TiemannBoege I 2013 New evidence for positive selection helps explain the paternal age effect observed in achondroplasia. Human Molecular Genetics 22 4117-4126. (doi:10.1093/hmg/ddt260)

Shroff R 2013 Phosphate is a vascular toxin. Pediatric Nephrology 28 583-593. (doi:10.1007/s00467-012-2347-x)

Shukla V, Coumoul X, Wang RH, Kim HS \& Deng CX 2007 RNA interference and inhibition of MEK-ERK signaling prevent abnormal skeletal phenotypes in a mouse model of craniosynostosis. Nature Genetics 39 1145-1150. (doi:10.1038/ng2096)

Shung CY, Ota S, Zhou ZQ Keene DR \& Hurlin PJ 2012 Disruption of a Sox9- $\beta$-catenin circuit by mutant Fgfr3 in thanatophoric dysplasia type II. Human Molecular Genetics 21 4628-4644. (doi:10.1093/hmg/dds305)

Sirbu IO, Zhao X \& Duester G 2008 Retinoic acid controls heart anteroposterior patterning by down-regulating Isl1 through the $F g f 8$ pathway. Developmental Dynamics 237 1627-1635. (doi:10.1002/dvdy. 21570)

Sobue T, Naganawa T, Xiao L, Okada Y, Tanaka Y, Ito M, Okimoto N, Nakamura T, Coffin JD \& Hurley MM 2005 Over-expression of fibroblast growth factor- 2 causes defective bone mineralization and osteopenia in transgenic mice. Journal of Cellular Biochemistry 95 83-94. (doi:10.1002/ jcb.20389)

Su WC, Kitagawa M, Xue N, Xie B, Garofalo S, Cho J, Deng C, Horton WA \& Fu XY 1997 Activation of Stat1 by mutant fibroblast growth-factor receptor in thanatophoric dysplasia type II dwarfism. Nature $\mathbf{3 8 6}$ 288-292. (doi:10.1038/386288a0)

Su N, Sun Q, Li C, Lu X, Qi H, Chen S, Yang J, Du X, Zhao L, He Q et al. 2010 Gain-of-function mutation in FGFR3 in mice leads to decreased bone mass by affecting both osteoblastogenesis and osteoclastogenesis. Human Molecular Genetics 19 1199-1210. (doi:10.1093/hmg/ddp590) 
Suzuki H, Suda N, Shiga M, Kobayashi Y, Nakamura M, Iseki S \& Moriyama K 2012 Apert syndrome mutant FGFR2 and its soluble form reciprocally alter osteogenesis of primary calvarial osteoblasts. Journal of Cellular Physiology 227 3267-3277. (doi:10.1002/jcp.24021)

Szebenyi G, Savage MP, Olwin BB \& Fallon JF 1995 Changes in the expression of fibroblast growth factor receptors mark distinct stages of chondrogenesis in vitro and during chick limb skeletal patterning. Developmental Dynamics 204 446-456. (doi:10.1002/aja.1002040410)

Tanaka E, Ishino Y, Sasaki A, Hasegawa T, Watanabe M, Dalla-Bona DA, Yamano E, van Eijden TM \& Tanne K 2006 Fibroblast growth factor-2 augments recombinant human bone morphogenetic protein-2induced osteoinductive activity. Annals of Biomedical Engineering 34 717-725. (doi:10.1007/s10439-006-9092-x)

Tanimoto Y, Yokozeki M, Hiura K, Matsumoto K, Nakanishi H, Matsumoto T, Marie PJ \& Moriyama K 2004 A soluble form of fibroblast growth factor receptor 2 (FGFR2) with S252W mutation acts as an efficient inhibitor for the enhanced osteoblastic differentiation caused by FGFR2 activation in Apert syndrome. Journal of Biological Chemistry 279 45926-45934. (doi:10.1074/jbc.M404824200)

Tavormina PL, Shiang R, Thompson LM, Zhu YZ, Wilkin DJ, Lachman RS, Wilcox WR, Rimoin DL, Cohn DH \& Wasmuth JJ 1995 Thanatophoric dysplasia (types I and II) caused by distinct mutations in fibroblast growth factor receptor 3. Nature Genetics 9 321-328. (doi:10.1038/ ng0395-321)

Toydemir RM, Brassington AE, Bayrak-Toydemir P, Krakowiak PA, Jorde LB, Whitby FG, Longo N, Viskochil DH, Carey JC \& Bamshad MJ 2006 A novel mutation in FGFR3 causes camptodactyly, tall stature, and hearing loss (CATSHL) syndrome. American Journal of Human Genetics 79 935-941. (doi:10.1086/508433)

Trebicz-Geffen M, Nevo Z, Evron Z, Posternak N, Glaser T, Fridkin M, Kollander Y \& Robinson D 2003 The short-lived exostosis induced surgically versus the lasting genetic hereditary multiple exostoses. Experimental and Molecular Pathology 74 40-48. (doi:10.1016/S00144800(03)80007-2)

Trudel S, Stewart AK, Rom E, Wei E, Li ZH, Kotzer S, Chumakov I, Singer Y, Chang H, Liang SB et al. 2006 The inhibitory anti-FGFR3 antibody, PRO-001, is cytotoxic to $\mathrm{t}(4 ; 14)$ multiple myeloma cells. Blood $\mathbf{1 0 7}$ 4039-4046. (doi:10.1182/blood-2005-10-4179)

Turnquist J, Ornoy A, Eini D \& Schwartz Z 1992 Effects of $1 \alpha(\mathrm{OH})$-vitamin $\mathrm{D}_{3}$ and $24,25(\mathrm{OH})_{2}$-vitamin $\mathrm{D}_{3}$ on long bones of glucocorticoid-treated rats. Acta Anatomica 145 61-67. (doi:10.1159/000147343)

Twigg SR, Healy C, Babbs C, Sharpe JA, Wood WG, Sharpe PT, Morriss-Kay GM \& Wilkie AO 2009 Skeletal analysis of the Fgfr $3_{\text {P244R }}$ mouse, a genetic model for the Muenke craniosynostosis syndrome. Developmental Dynamics 238 331-342. (doi:10.1002/dvdy.21790)

Uchii M, Tamura T, Suda T, Kakuni M, Tanaka A \& Miki I 2008 Role of fibroblast growth factor 8 (FGF8) in animal models of osteoarthritis. Arthritis Research \& Therapy 10 R90. (doi:10.1186/ar2474)

Ueda K, Yamanaka Y, Harada D, Yamagami E, Tanaka H \& Seino Y 2007 PTH has the potential to rescue disturbed bone growth in achondroplasia. Bone 41 13-18. (doi:10.1016/j.bone.2007.02.028)

Ueno H, Huang X, Tanaka Y \& Hirokawa N 2011 KIF16B/Rab14 molecular motor complex is critical for early embryonic development by transporting FGF receptor. Developmental Cell 20 60-71. (doi:10.1016/j. devcel.2010.11.008)

Valta MP, Hentunen T, Qu Q, Valve EM, Harjula A, Seppanen JA, Vaananen HK \& Harkonen PL 2006 Regulation of osteoblast differentiation: a novel function for fibroblast growth factor 8. Endocrinology 147 2171-2182. (doi:10.1210/en.2005-1502)

Valverde-Franco G, Liu H, Davidson D, Chai S, Valderrama-Carvajal H Goltzman D, Ornitz DM \& Henderson JE 2004 Defective bone mineralization and osteopenia in young adult FGFR3 ${ }^{-1-}$ mice. Human Molecular Genetics 13 271-284. (doi:10.1093/hmg/ddh034)

Valverde-Franco G, Binette JS, Li W, Wang H, Chai S, Laflamme F, TranKhanh N, Quenneville E, Meijers T, Poole AR et al. 2006 Defects in articular cartilage metabolism and early arthritis in fibroblast growth factor receptor 3 deficient mice. Human Molecular Genetics 15 1783-1792. (doi:10.1093/hmg/ddl100)

Verheyden JM \& Sun X 2008 An Fgf/Gremlin inhibitory feedback loop triggers termination of limb bud outgrowth. Nature $\mathbf{4 5 4} 638-641$. (doi:10.1038/nature07085)

Vidrich A, Buzan JM, Brodrick B, Ilo C, Bradley L, Fendig KS, Sturgill T \& Cohn SM 2009 Fibroblast growth factor receptor-3 regulates Paneth cell lineage allocation and accrual of epithelial stem cells during murine intestinal development. American Journal of Physiology. Gastrointestinal and Liver Physiology 297 G168-G178. (doi:10.1152/ajpgi.90589.2008)

Wang Y, Spatz MK, Kannan K, Hayk H, Avivi A, Gorivodsky M, Pines M, Yayon A, Lonai P \& Givol D 1999 A mouse model for achondroplasia produced by targeting fibroblast growth factor receptor 3. PNAS 96 4455-4460. (doi:10.1073/pnas.96.8.4455)

Wang JM, Du XL, Li CL, Yin LJ, Chen B, Sun J, Su N, Zhao L, Song RH, Song WW et al. 2004 Gly374Arg mutation in Fgfr3 causes achondroplasia in mice. Zhonghua Yi Xue Yi Chuan Xue Za Zhi 21 537-541.

Wang Y, Xiao R, Yang F, Karim BO, Iacovelli AJ, Cai J, Lerner CP, Richtsmeier JT, Leszl JM, Hill CA et al. 2005 Abnormalities in cartilage and bone development in the Apert syndrome FGFR2 +/s252W mouse. Development 132 3537-3548. (doi:10.1242/dev.01914)

Wang Y, Zhou X, Oberoi K, Phelps R, Couwenhoven R, Sun M, Rezza A, Holmes G, Percival CJ, Friedenthal J et al. 2012 p38 Inhibition ameliorates skin and skull abnormalities in Fgfr 2 Beare-Stevenson mice. Journal of Clinical Investigation 122 2153-2164. (doi:10.1172/JCI62644)

Weinstein M, Xu X, Ohyama K \& Deng CX 1998 FGFR-3 and FGFR-4 function cooperatively to direct alveogenesis in the murine lung. Development 125 3615-3623.

Weng T, Yi L, Huang J, Luo F, Wen X, Du X, Chen Q, Deng C, Chen D \& Chen L 2012 Genetic inhibition of fibroblast growth factor receptor 1 in knee cartilage attenuates the degeneration of articular cartilage in adult mice. Arthritis and Rheumatism 64 3982-3992. (doi:10.1002/art.34645)

White KE, Evans WE, O'Riordan JLH, Speer MC, Econs MJ, LorenzDepiereux B, Grabowski M, Meitinger T \& Strom TM 2000 Autosomal dominant hypophosphataemic rickets is associated with mutations in FGF23. Nature Genetics 26 345-348. (doi:10.1038/81664)

White KE, Cabral JM, Davis SI, Fishburn T, Evans WE, Ichikawa S, Fields J, Yu X, Shaw NJ, McLellan NJ et al. 2005 Mutations that cause osteoglophonic dysplasia define novel roles for FGFR1 in bone elongation. American Journal of Human Genetics 76 361-367. (doi:10.1086/427956)

Whitehead CC, McCormack HA, McTeir L \& Fleming RH 2004 High vitamin $\mathrm{D}_{3}$ requirements in broilers for bone quality and prevention of tibial dyschondroplasia and interactions with dietary calcium, available phosphorus and vitamin A. British Poultry Science 45 425-436. (doi:10.1080/00071660410001730941)

Wilkes D, Rutland P, Pulleyn LJ, Reardon W, Moss C, Ellis JP, Winter RM \& Malcolm S 1996 A recurrent mutation, ala391glu, in the transmembrane region of FGFR3 causes Crouzon syndrome and acanthosis nigricans. Journal of Medical Genetics 33 744-748. (doi:10.1136/jmg.33. 9.744)

Wilkie AO 2005 Bad bones, absent smell, selfish testes: the pleiotropic consequences of human FGF receptor mutations. Cytokine \& Growth Factor Reviews 16 187-203. (doi:10.1016/j.cytogfr.2005.03.001)

Wilkinson CC, Manchester DK, Keating RF, Ketch LL \& Winston KR 2012 Syndromic craniosynostosis, fibroblast growth factor receptor 2 (FGFR2) mutations, and sacrococcygeal eversion presenting as human tails. Child's Nervous System 28 1221-1226. (doi:10.1007/s00381-012 1813-x)

Wohrle S, Bonny O, Beluch N, Gaulis S, Stamm C, Scheibler M, Muller M, Kinzel B, Thuery A, Brueggen J et al. 2011 FGF receptors control vitamin $\mathrm{D}$ and phosphate homeostasis by mediating renal FGF-23 signaling and regulating FGF-23 expression in bone. Journal of Bone and Mineral Research 26 2486-2497. (doi:10.1002/jbmr.478)

Wohrle S, Henninger C, Bonny O, Thuery A, Beluch N, Hynes NE, Guagnano V, Sellers WR, Hofmann F, Kneissel M et al. 2013 
Pharmacological inhibition of fibroblast growth factor (FGF) receptor signaling ameliorates FGF23-mediated hypophosphatemic rickets. Journal of Bone and Mineral Research 28 899-911. (doi:10.1002/jbmr. 1810)

Wu XL, Gu MM, Huang L, Liu XS, Zhang HX, Ding XY, Xu JQ, Cui B, Wang L, Lu SY et al. 2009 Multiple synostoses syndrome is due to a missense mutation in exon 2 of FGF9 gene. American Journal of Human Genetics $\mathbf{8 5}$ 53-63. (doi:10.1016/j.ajhg.2009.06.007)

Wu S, Levenson A, Kharitonenkov A \& De Luca F 2012 Fibroblast growth factor 21 (FGF21) inhibits chondrocyte function and growth hormone action directly at the growth plate. Journal of Biological Chemistry $\mathbf{2 8 7}$ 26060-26067. (doi:10.1074/jbc.M112.343707)

Wuelling M \& Vortkamp A 2010 Transcriptional networks controlling chondrocyte proliferation and differentiation during endochondral ossification. Pediatric Nephrology 25 625-631. (doi:10.1007/s00467-0091368-6)

Xiao L, Naganawa T, Obugunde E, Gronowicz G, Ornitz DM, Coffin JD \& Hurley MM 2004 Stat 1 controls postnatal bone formation by regulating fibroblast growth factor signaling in osteoblasts. Journal of Biological Chemistry 279 27743-27752. (doi:10.1074/jbc.M314323200)

Xiao L, Liu P, Li X, Doetschman T, Coffin JD, Drissi H \& Hurley MM 2009 Exported $18-\mathrm{kDa}$ isoform of fibroblast growth factor-2 is a critical determinant of bone mass in mice. Journal of Biological Chemistry 284 3170-3182. (doi:10.1074/jbc.M804900200)

Xiao L, Naganawa T, Lorenzo J, Carpenter TO, Coffin JD \& Hurley MM 2010 Nuclear isoforms of fibroblast growth factor 2 are novel inducers of hypophosphatemia via modulation of FGF23 and KLOTHO. Journal of Biological Chemistry 285 2834-2846. (doi:10.1074/jbc.M109.030577)

Xiao L, Esliger A \& Hurley MM 2013 Nuclear fibroblast growth factor 2 (FGF2) isoforms inhibit bone marrow stromal cell mineralization through FGF23/FGFR/MAPK in vitro. Journal of Bone and Mineral Research 28 35-45. (doi:10.1002/jbmr.1721)

Xie Y, Su N, Jin M, Qi H, Yang J, Li C, Du X, Luo F, Chen B, Shen Y et al. 2012 Intermittent PTH (1-34) injection rescues the retarded skeletal development and postnatal lethality of mice mimicking human achondroplasia and thanatophoric dysplasia. Human Molecular Genetics 21 3941-3955. (doi:10.1093/hmg/dds181)

Xu X, Weinstein M, Li C, Naski M, Cohen RI, Ornitz DM, Leder P \& Deng C 1998 Fibroblast growth factor receptor 2 (FGFR2)-mediated reciprocal regulation loop between FGF8 and FGF10 is essential for limb induction. Development 125 753-765.

Yamaguchi TP, Harpal K, Henkemeyer M \& Rossant J $1994 f g f r-1$ is required for embryonic growth and mesodermal patterning during mouse gastrulation. Genes and Development 8 3032-3044. (doi:10.1101/gad.8. 24.3032)

Yamamoto K, Utsunomiya A, Tobinai K, Tsukasaki K, Uike N, Uozumi K, Yamaguchi K, Yamada Y, Hanada S, Tamura K et al. 2010 Phase I study of KW-0761, a defucosylated humanized anti-CCR4 antibody, in relapsed patients with adult T-cell leukemia-lymphoma and peripheral T-cell lymphoma. Journal of Clinical Oncology 28 1591-1598. (doi:10.1200/JCO.2009.25.3575)

Yamanaka Y, Tanaka H, Koike M, Nishimura R \& Seino Y 2003 PTHrP rescues ATDC5 cells from apoptosis induced by FGF receptor 3 mutation. Journal of Bone and Mineral Research 18 1395-1403. (doi:10.1359/jbmr.2003.18.8.1395)

Yang X, Harkins LK, Zubanova O, Harrington A, Kovalenko D, Nadeau RJ, Chen PY, Toher JL, Lindner V, Liaw L et al. 2008 Overexpression of Spry1 in chondrocytes causes attenuated FGFR ubiquitination and sustained ERK activation resulting in chondrodysplasia. Developmental Biology 321 64-76. (doi:10.1016/j.ydbio.2008.05.555)

Yano F, Saito T, Ogata N, Yamazawa T, Iino M, Chung UI \& Kawaguchi H $2013 \beta$-catenin regulates parathyroid hormone/parathyroid hormonerelated protein receptor signals and chondrocyte hypertrophy through binding to the intracellular C-terminal region of the receptor. Arthritis and Rheumatism 65 429-435. (doi:10.1002/art.37779)

Yasoda A \& Nakao K 2010 Translational research of C-type natriuretic peptide (CNP) into skeletal dysplasias. Endocrine Journal 57 659-666. (doi:10.1507/endocri.K10E-164)

Yin L, Du X, Li C, Xu X, Chen Z, Su N, Zhao L, Qi H, Li F, Xue J et al. 2008 Pro253Arg mutation in fibroblast growth factor receptor 2 (Fgfr2) causes skeleton malformation mimicking human Apert syndrome by affecting both chondrogenesis and osteogenesis. Bone 42 631-643. (doi:10.1016/j.bone.2007.11.019)

Yoshiko Y, Wang H, Minamizaki T, Ijuin C, Yamamoto R, Suemune S, Kozai K, Tanne K, Aubin JE \& Maeda N 2007 Mineralized tissue cells are a principal source of FGF23. Bone $\mathbf{4 0}$ 1565-1573. (doi:10.1016/j.bone. 2007.01.017)

Yu X \& White KE 2005 FGF23 and disorders of phosphate homeostasis. Cytokine \& Growth Factor Reviews 16 221-232. (doi:10.1016/j.cytogfr. 2005.01.002)

Yu K \& Ornitz DM 2008 FGF signaling regulates mesenchymal differentiation and skeletal patterning along the limb bud proximodistal axis. Development 135 483-491. (doi:10.1242/dev.013268)

Yu K, Xu J, Liu Z, Sosic D, Shao J, Olson EN, Towler DA \& Ornitz DM 2003 Conditional inactivation of FGF receptor 2 reveals an essential role for FGF signaling in the regulation of osteoblast function and bone growth Development 130 3063-3074. (doi:10.1242/dev.00491)

Yu X, Ibrahimi OA, Goetz R, Zhang F, Davis SI, Garringer HJ, Linhardt RJ, Ornitz DM, Mohammadi M \& White KE 2005 Analysis of the biochemical mechanisms for the endocrine actions of fibroblast growth factor-23. Endocrinology 146 4647-4656. (doi:10.1210/en. 2005-0670)

Zhou YX, Xu X, Chen L, Li C, Brodie SG \& Deng CX 2000 A Pro250Arg substitution in mouse Fgfr 1 causes increased expression of Cbfa1 and premature fusion of calvarial sutures. Human Molecular Genetics 9 2001-2008. (doi:10.1093/hmg/9.13.2001)

Received in final form 13 June 2014

Accepted 10 July 2014 http://jme.endocrinology-journals.org DOI: 10.1530/JME-14-0012
() 2014 Society for Endocrinology Printed in Great Britain
Published by Bioscientifica Ltd 